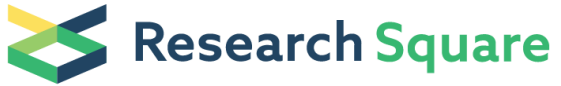 \\ Preprints are preliminary reports that have not undergone peer review. They should not be considered conclusive, used to inform clinical practice, or referenced by the media as validated information.
}

\section{Chromatin Landscape Dynamics in Development of the Plant Parasitic Nematode Meloidogyne Incognita}

\section{Rahim Hassanaly-Goulamhoussen}

Université Côte d'Azur Faculté des Sciences: Universite Cote d'Azur Faculte des Sciences

\section{Ronaldo De Carvalho Augusto}

Ecole Normale Superieure

\section{Nathalie Marteu-Garello}

INRAE PACA Site de Sophia: Institut National de Recherche pour l'Agriculture l'Alimentation et I'Environnement Provence-Alpes-Cote d'Azur Site de Sophia

\section{Arthur Péré}

INRAE PACA Site de Sophia: Institut National de Recherche pour l'Agriculture I'Alimentation et l'Environnement Provence-Alpes-Cote d'Azur Site de Sophia

\section{Bruno Favery}

INRAE PACA Site de Sophia: Institut National de Recherche pour l'Agriculture I'Alimentation et I'Environnement Provence-Alpes-Cote d'Azur Site de Sophia

\section{Martine Da Rocha}

INRAE PACA Site de Sophia: Institut National de Recherche pour l'Agriculture l'Alimentation et I'Environnement Provence-Alpes-Cote d'Azur Site de Sophia

\section{Etienne G.J. Danchin}

INRAE PACA Site de Sophia: Institut National de Recherche pour l'Agriculture l'Alimentation et I'Environnement Provence-Alpes-Cote d'Azur Site de Sophia

\section{Pierre Abad}

INRAE PACA Site de Sophia: Institut National de Recherche pour l'Agriculture l'Alimentation et I'Environnement Provence-Alpes-Cote d'Azur Site de Sophia

\section{Christoph Grunau}

Université de Perpignan: Universite de Perpignan

\section{Laetitia Perfus-Barbeoch Zurletto ( $\nabla$ laetitia.zurletto@univ-cotedazur.fr )}

Université Côte d'Azur https://orcid.org/0000-0003-4395-7913

\section{Research}

Keywords: Histone modifications, Epigenetics, Root-knot nematode, Development, Parasitism. 
Posted Date: June 28th, 2021

DOI: https://doi.org/10.21203/rs.3.rs-627100/v1

License: (c) (i) This work is licensed under a Creative Commons Attribution 4.0 International License. Read Full License 


\section{Abstract}

\section{Background:}

In model organisms, epigenome dynamics underlies a plethora of biological processes. The role of epigenetic modifications in development and parasitism in nematode pests remains unknown. The rootknot nematode Meloidogyne incognita adapts rapidly to unfavorable conditions, despite its asexual reproduction. However, the mechanisms underlying this remarkable plasticity and their potential impact on gene expression remain unknown.

\section{Results:}

This study provides the first insight into contribution of epigenetic mechanisms to this plasticity, by studying histone modifications in M. incognita. The distribution of five histone modifications revealed the existence of strong epigenetic signatures, similar to those found in the model nematode Caenorhabditis elegans. We investigated their impact on chromatin structure and their distribution relative to transposable elements (TE) loci. We assessed the influence of the chromatin landscape on gene expression at two developmental stages: eggs, and pre-parasitic juveniles. H3K4me3 histone modification was strongly correlated with high levels of expression for protein-coding genes implicated in stage-specific processes during $M$. incognita development.

\section{Conclusions:}

We provided new insights in the dynamic regulation of parasitism genes kept under histone modifications silencing. In this pioneering study, we establish a comprehensive framework for the importance of epigenetic mechanisms in the regulation of the genome expression and its stability in plant-parasitic nematodes.

\section{Background}

Crops are continually attacked by a wide range of pests and parasites. Plant-parasitic nematodes are thought to be one of the main causes of damages in food crops, resulting in yield losses of more than $\$ 150$ billion worldwide [1]. Root knot nematodes (RKN), Meloidogyne spp, are among the most rapidly spreading of all crop pests and pathogens [2]. Their rapid spread may have been facilitated by their wide host range, high fecundity, and parthenogenetic reproduction, allowing infestations to become established with relatively few individuals [1]. Understanding the determinants of the extreme adaptive capacity of RKN is crucial for the development of effective and sustainable control methods.

Meloidogyne incognita is the most ubiquitous RKN with an obligate biotroph lifestyle. It feeds exclusively on living cells within the vascular cylinder of the root [3]. The freshly hatched second-stage pre-parasitic juveniles (J2s) within the soil are attracted to the root tip of the host plant. These microscopic J2s (400 $\mu \mathrm{m}$ long and $15 \mu \mathrm{m}$ wide) invade host roots close to the root elongation zone, through the physical and 
enzymatic destruction of plant cell walls in the root epidermis, eventually reaching the vascular cylinder, where they establish a permanent feeding site [4]. To this end, infective juveniles secrete molecules known as effectors, to induce major cellular changes in recipient host cells and evade plant defense responses. These effector proteins are translocated directly from the secretory gland cells into the host cells by a syringe-like structure, called stylet [5]. The tissue around the permanent feeding site typically shows signs of hyperplasia, resulting in the characteristic knot-like shape of roots infected with RKN. Once they begin feeding, the J2s become sedentary, going through three molts before becoming mature adults. The females release eggs onto the root surface, and embryogenesis within the eggs is followed by the first molt, generating second-stage juveniles. Males are produced in unfavorable conditions (e.g., resistant host), and they migrate out of the plant without developing further and without playing a role in reproduction [6].

Despite its mitotic parthenogenetic mode of reproduction, presumably resulting in low genetic plasticity, M. incognita can adapt rapidly to unfavorable conditions $[7,8]$. The mechanisms underlying this adaptability have yet to be elucidated. Population genomics analyses have revealed only low genome variability at the SNP level between $M$. incognita isolates across the globe [8]. Furthermore, these point mutations did not correlate with the ranges of compatible plant host species. A follow-up population genomics study on Japanese isolates [9] confirmed the low genome variability at the SNP level but identified some correlations with infection compatibility of different cultivars of the same plant species (sweet potato). Taken together, these studies suggest point mutations are not the sole genome plasticity factors involved in the adaptive evolution of $M$. incognita. Consequently, other genome plasticity factors have also been investigated in this species, including movements of transposable elements (TE) and gene copy number variations (CNV). High similarity between TE copies and their consensus sequences suggest they have been recently active in the $M$. incognita genome [10]. Studying variations of their frequencies across geographical isolates allowed identification of isolate-specific TE insertions, including in coding or regulatory regions, suggesting TE movements might constitute a genome plasticity factor with functional consequences. However, no evidence yet for an adaptive role of these movements were shown in this species and nothing is known about the mechanisms underlying their regulation or amplification. In addition, convergent gene CNV have been shown to correlate with rapid breaking down of tomato plant resistance, suggesting an adaptive role, although causative relation has not yet been shown [11] and the underlying mechanisms are also unknown. Because a strategy to explain $M$. incognita's capacity to adapt in a fast-fluctuating environment is lacking, investigating whether epigenetic mechanisms do occur and have possible impact on genome regulation is timely. Indeed, the epigenetic control of transposable elements has been identified as an important factor of genome evolution [12]. Furthermore, the epigenome dynamics of multicellular organisms are associated with transitions in cell cycle development, germline specification, gametogenesis, and inheritance. Within the cell, nuclear DNA is packaged and ordered into chromatin by histone proteins $[13,14]$. Chromatin can adopt different conformational states directly influencing gene expression, from relaxed transcriptionally active euchromatin to condensed transcriptionally inactive heterochromatin. Specific enzymes regulate histone structure and function throuah chemical modifications th the histone proteins, such as acetylation and Loading [MathJax]/jax/output/CommonHTML/fonts/TeX/fontdata.js

Page 4/40 
methylation. In many organisms, euchromatin displays an enrichment in the di- (or tri-) methylation of the lysine 4 residue of histone 3 (H3K4me3), whereas heterochromatin displays enrichment in the trimethylation of the lysine 9 or lysine 27 residue of histone 3 (H3K9me3 and H3K27me3) [15]. Specific combinations of histone modifications are associated with transcriptionally permissive or repressive chromatin structures, thereby controlling gene expression at the transcriptional level [16]. Other organisms, such as Saccharomyces cerevisiae, display an unusual regulation of histone modifications, with a lack of $\mathrm{H} 3 \mathrm{~K} 9 \mathrm{me} 3$ modification and the establishment of alternative modifications defining the silent state of chromatin [17].

Chromatin immunoprecipitation followed by high-throughput sequencing (ChIP-seq) is a powerful method for generating genome-wide maps of interactions between proteins and DNA, including posttranslational histone modifications, and for mapping histone variants [18]. Extensive epigenetic studies have been performed in the model nematode Caenorhabditis elegans, addressing its functional genomic elements, including histone modifications in response to the environment [19]. Previous studies have shown that $M$. incognita lacks 5-methylcytosine $(5 \mathrm{mC})$ and has no cytosine-DNA (cytosine-5)methyltransferase 1 (DNMT1) or DNMT3 $[20,21]$ which is similar to what is known for $C$. elegans [22]. Low-level DNA N(6)-methylation (6mA-DNA) has been identified as an alternative carrier of epigenetic information in $C$. elegans [23]. However, the physiological relevance of 6-mA-DNA remains unclear. Apart from this model species, the role of chromatin modifications has not been studied in nematodes. The studies performed to date have been limited to bioinformatics analyses indicating that potential homologs of canonical histone-modifying enzymes are conserved in the genomes of $C$. elegans and two parasitic nematodes, the food-borne animal parasite Trichinella spiralis and the plant parasite $M$. incognita [21,24]. Epigenetic regulation is considered a key mechanism of parasite adaptation, and its role in plant-nematode interactions is an emerging field of study [25].

Deciphering histone modifications and their effects on gene transcription is important for understanding the key parameters underlying biological processes, including parasitic success in RKN. This study provides the first insight of the genome-wide epigenetic landscape of $M$. incognita and its direct relationship to gene transcription. Using ChIP-seq, we first analyzed the distribution of five posttranslational histone modifications. We then investigated the impact of these modifications on chromatin structure and their co-distribution relative to TE-rich regions. Finally, we assessed the influence of the chromatin landscape on gene expression during developmental, with a focus on parasitism genes, such as those encoding effectors.

\section{Results}

The chromatin landscape of five histone modifications in $\mathrm{M}$. incognita

We performed ChIP-Seq analysis to study posttranslational histone modifications in M. incognita. We first checked the specificity of a set of commercially available antibodies and optimized the binding and coniratinn ctone Enur nut of 15 availahlo antihndioc nroviously used in C. elegans passed the two-step Loading [MathJax]/jax/output/CommonHTML/fonts/TeX/fontdata.js 
validation process [26]. These antibodies gave single bands on western blots and saturated signals on ChIP-titration (S1 Fig, S1 Table). They were raised specifically against H3K27ac, H4K20me1, H3K9me3 and H3K27me3, and were added to the first previously validated antibody raised against H3K4me3 [20]. ChIP-Seq data were obtained for two RKN developmental stages, eggs and pre-parasitic juveniles 2 (J2s), and were mapped to the most complete annotated $M$. incognita genome publicly available [27]. Regions displaying a specific enrichment in histone modifications were identified (S2 Fig), making study of the chromatin landscape based on these five histone modifications meaningful.

We investigated the distribution of histone modifications in the $M$. incognita genome further, by calculating the genomic frequencies of each histone modification and of the 31 histone modification combinations detected genome-wide (Table 1). These frequencies correspond to the percentage of the total genome ( $184 \mathrm{Mb}$ divided by a bin size of $500 \mathrm{bp}$ each) covered by each histone modification. In both eggs and $\mathrm{J} 2 \mathrm{~s}, \mathrm{H} 3 \mathrm{~K} 4 \mathrm{me} 3$ was the most prevalent histone modification, covering $13.9 \%$ and $14.6 \%$ of the genome, respectively. By contrast, $\mathrm{H} 3 \mathrm{~K} 9 \mathrm{me} 3, \mathrm{H} 3 \mathrm{~K} 27 \mathrm{me} 3, \mathrm{H} 4 \mathrm{~K} 20 \mathrm{me} 1$ and H3K27ac each covered less than $4 \%$ of the genome. Very little difference in the frequencies of these modifications was observed between eggs and J2s (Table 1).

Histone modifications can act together in a combinatorial manner to exert different effects on the genome. The most frequent histone combinations observed in both eggs and J2s involved H4K20me1+ H3K27me3, or H4K2Ome1 + H3K9me3, or H4K20me1 + H3K27me3 + H3K9me3, with frequencies ranging between $1.3 \%$ and $2 \%$. The other 23 combinations presented relatively low coverage, with a frequency of less than $1 \%$. In total, $~ 35 \%$ of the $M$. incognita genome was covered by the five histone modifications and their combinations (Table 1). Overall, these results reveal a consistent chromatin landscape during M. incognita eggs-to-J2s transition based on the five post translational histone modifications considered here. 
Table 1

Overall coverage frequencies of ChIP-Seq data.

\begin{tabular}{|c|c|c|c|c|c|c|}
\hline $\begin{array}{l}\text { Histone } \\
\text { modification } \\
\text { combination }\end{array}$ & $\begin{array}{l}\text { Whole- } \\
\text { genome } \\
\text { coverage } \\
\text { in eggs } \\
\text { (bp) }\end{array}$ & $\begin{array}{l}\text { Whole- } \\
\text { genome } \\
\text { coverage } \\
\text { in J2s (bp) }\end{array}$ & $\begin{array}{l}\text { Proportion } \\
\text { of whole } \\
\text { genome in } \\
\text { eggs (\%) }\end{array}$ & $\begin{array}{l}\text { Proportion } \\
\text { of whole } \\
\text { genome in } \\
\text { J2s (\%) }\end{array}$ & $\begin{array}{l}\text { Proportion } \\
\text { in TE in } \\
\text { eggs (\%) }\end{array}$ & $\begin{array}{l}\text { Proportion } \\
\text { in TE in } \\
\mathrm{J} 2 \mathrm{~s}(\%)\end{array}$ \\
\hline [H3K4me3] & $25,235,500$ & $26,575,000$ & 13.861 & 14.597 & 2.899 & 3.129 \\
\hline [H4K20me1] & $6,900,000$ & $6,535,000$ & 3.79 & 3.59 & 1.747 & 2.104 \\
\hline [H3K9me3] & $6,379,000$ & $6,033,500$ & 3.504 & 3.314 & 8.614 & 7.108 \\
\hline [H3K27me3] & $4,036,000$ & $5,004,500$ & 2.217 & 2.749 & 1.73 & 2.421 \\
\hline $\begin{array}{l}{[\mathrm{H} 3 \mathrm{~K} 9 \mathrm{me} 3+} \\
\text { H4K20me1] }\end{array}$ & $3,676,500$ & $3,062,500$ & 2.019 & 1.682 & 5.944 & 4.756 \\
\hline [H3K27ac] & $2,991,500$ & $2,528,000$ & 1.643 & 1.389 & 0.434 & 0.386 \\
\hline $\begin{array}{l}\text { [H3K27me3 + } \\
\text { H3K9me3 + } \\
\text { H4K20me1] }\end{array}$ & $2,737,500$ & $2,499,500$ & 1.504 & 1.373 & 4.283 & 4.05 \\
\hline $\begin{array}{l}{[\mathrm{H} 3 \mathrm{~K} 27 \mathrm{me} 3+} \\
\text { H4K20me1] }\end{array}$ & $2,698,000$ & $3,431,500$ & 1.482 & 1.885 & 1.387 & 2.239 \\
\hline $\begin{array}{l}\text { [H3K27ac+ } \\
\text { H4K20me1] }\end{array}$ & $1,857,500$ & $1,478,000$ & 1.02 & 0.812 & 0.29 & 0.214 \\
\hline $\begin{array}{l}\text { [H3K4me3 + } \\
\text { H3K9me3] }\end{array}$ & $1,580,500$ & 836,000 & 0.868 & 0.459 & 0.18 & 0.115 \\
\hline $\begin{array}{l}\text { [H3K27ac+ } \\
\text { H3K27me3+ } \\
\text { H4K20me1] }\end{array}$ & $1,519,000$ & $1,643,500$ & 0.834 & 0.903 & 0.362 & 0.434 \\
\hline $\begin{array}{l}\text { [H3K4me3+ } \\
\text { H4K20me1] }\end{array}$ & $1,263,500$ & $1,263,000$ & 0.694 & 0.694 & 0.194 & 0.168 \\
\hline $\begin{array}{l}\text { [H3K27ac+ } \\
\text { H3K4me3] }\end{array}$ & 685,000 & 624,500 & 0.376 & 0.343 & 0.091 & 0.082 \\
\hline $\begin{array}{l}\text { [H3K27me3 + } \\
\text { H3K9me3] }\end{array}$ & 657,500 & 656,000 & 0.361 & 0.36 & 0.643 & 0.617 \\
\hline $\begin{array}{l}\text { [H3K27ac + } \\
\text { H3K27me3 + } \\
\text { H3K9me3 + } \\
\text { H4K20me1] }\end{array}$ & 545,000 & 403,500 & 0.299 & 0.222 & 0.792 & 0.379 \\
\hline $\begin{array}{l}\text { [H3K27ac+ } \\
\text { H3K27me3] }\end{array}$ & 481,000 & 544,500 & 0.264 & 0.299 & 0.096 & 0.089 \\
\hline
\end{tabular}




\begin{tabular}{|c|c|c|c|c|c|c|}
\hline $\begin{array}{l}\text { Histone } \\
\text { modification } \\
\text { combination }\end{array}$ & $\begin{array}{l}\text { Whole- } \\
\text { genome } \\
\text { coverage } \\
\text { in eggs } \\
\text { (bp) }\end{array}$ & $\begin{array}{l}\text { Whole- } \\
\text { genome } \\
\text { coverage } \\
\text { in J2s (bp) }\end{array}$ & $\begin{array}{l}\text { Proportion } \\
\text { of whole } \\
\text { genome in } \\
\text { eggs (\%) }\end{array}$ & $\begin{array}{l}\text { Proportion } \\
\text { of whole } \\
\text { genome in } \\
\mathrm{J} 2 \mathrm{~s}(\%)\end{array}$ & $\begin{array}{l}\text { Proportion } \\
\text { in TE in } \\
\text { eggs (\%) }\end{array}$ & $\begin{array}{l}\text { Proportion } \\
\text { in TE in } \\
\mathrm{J} 2 \mathrm{~s}(\%)\end{array}$ \\
\hline $\begin{array}{l}\text { [H3K27ac+ } \\
\text { H3K4me3 + } \\
\text { H4K20me1] }\end{array}$ & 480,000 & 439,000 & 0.264 & 0.241 & 0.053 & 0.05 \\
\hline $\begin{array}{l}{[\mathrm{H} 3 \mathrm{~K} 4 \mathrm{me} 3+} \\
\text { H3K9me3+ } \\
\text { H4K20me1] }\end{array}$ & 258,000 & 164,500 & 0.142 & 0.09 & 0.098 & 0.06 \\
\hline $\begin{array}{l}\text { [H3K27ac + } \\
\text { H3K9me3 + } \\
\text { H4K20me1] }\end{array}$ & 251,000 & 221,000 & 0.138 & 0.121 & 0.238 & 0.072 \\
\hline $\begin{array}{l}{[\mathrm{H} 3 \mathrm{~K} 27 \mathrm{me} 3+} \\
\text { H3K4me3] }\end{array}$ & 194,500 & 188,500 & 0.107 & 0.104 & 0.031 & 0.022 \\
\hline $\begin{array}{l}\text { [H3K27ac+ } \\
\text { H3K9me3] }\end{array}$ & 149,000 & 246,000 & 0.082 & 0.135 & 0.034 & 0.038 \\
\hline $\begin{array}{l}\text { [H3K27ac + } \\
\text { H3K4me3 + } \\
\text { H3K9me3] }\end{array}$ & 108,500 & 67,000 & 0.06 & 0.037 & 0.019 & 0.017 \\
\hline $\begin{array}{l}\text { [H3K27ac + } \\
\text { H3K4me3 + } \\
\text { H3K9me3 + } \\
\text { H4K20me1] }\end{array}$ & 109,500 & 76,500 & 0.06 & 0.042 & 0.043 & 0.024 \\
\hline $\begin{array}{l}\text { [H3K27ac+ } \\
\text { H3K27me3 + } \\
\text { H3K4me3 }+ \\
\text { H3K9me3 }+ \\
\text { H4K20me1] }\end{array}$ & 94,500 & 75,000 & 0.052 & 0.041 & 0.154 & 0.086 \\
\hline $\begin{array}{l}\text { [H3K27ac + } \\
\text { H3K27me3 + } \\
\text { H3K4me3 + } \\
\text { H4K20me1] }\end{array}$ & 91,000 & 109,500 & 0.05 & 0.06 & 0.014 & 0.022 \\
\hline $\begin{array}{l}\text { [H3K27me3 + } \\
\text { H3K4me3 + } \\
\text { H4K20me1] }\end{array}$ & 63,000 & 76,500 & 0.035 & 0.042 & 0.007 & 0.017 \\
\hline $\begin{array}{l}\text { [H3K27me3 + } \\
\text { H3K4me3 + } \\
\text { H3K9me3 + } \\
\text { H4K20me1] }\end{array}$ & 55,000 & 28,000 & 0.03 & 0.015 & 0.036 & 0.046 \\
\hline $\begin{array}{l}{[\mathrm{H} 3 \mathrm{~K} 27 \mathrm{ac}+} \\
\text { H3K27me3 + } \\
\text { H3K9me3] }\end{array}$ & 49,000 & 92,500 & 0.027 & 0.051 & 0.017 & 0.026 \\
\hline
\end{tabular}




\begin{tabular}{|c|c|c|c|c|c|c|}
\hline $\begin{array}{l}\text { Histone } \\
\text { modification } \\
\text { combination }\end{array}$ & $\begin{array}{l}\text { Whole- } \\
\text { genome } \\
\text { coverage } \\
\text { in eggs } \\
\text { (bp) }\end{array}$ & $\begin{array}{l}\text { Whole- } \\
\text { genome } \\
\text { coverage } \\
\text { in J2s (bp) }\end{array}$ & $\begin{array}{l}\text { Proportion } \\
\text { of whole } \\
\text { genome in } \\
\text { eggs (\%) }\end{array}$ & $\begin{array}{l}\text { Proportion } \\
\text { of whole } \\
\text { genome in } \\
\mathrm{J} 2 \mathrm{~s}(\%)\end{array}$ & $\begin{array}{l}\text { Proportion } \\
\text { in TE in } \\
\text { eggs (\%) }\end{array}$ & $\begin{array}{l}\text { Proportion } \\
\text { in TE in } \\
\mathrm{J} 2 \mathrm{~s}(\%)\end{array}$ \\
\hline $\begin{array}{l}\text { [H3K27me3 + } \\
\text { H3K4me3 + } \\
\text { H3K9me3] }\end{array}$ & 44,000 & 21,500 & 0.024 & 0.012 & 0.017 & 0.007 \\
\hline $\begin{array}{l}\text { [H3K27ac+ } \\
\text { H3K27me3 + } \\
\text { H3K4me3] }\end{array}$ & 25,500 & 33,000 & 0.014 & 0.018 & 0.007 & 0.014 \\
\hline $\begin{array}{l}\text { [H3K27ac + } \\
\text { H3K27me3 + } \\
\text { H3K4me3 + } \\
\text { H3K9me3] }\end{array}$ & 6,500 & 13,500 & 0.004 & 0.007 & 0 & 0 \\
\hline Total & $65,222,000$ & $64,970,500$ & 35.825 & 35.687 & 30.454 & 28.792 \\
\hline
\end{tabular}

Overall alignment (bp) and genomic coverage percentage of H3K4me3, H3K9me3, H3K27ac, H3K27me3 and H4K20me1 histone modifications and their combinations over the whole $M$. incognita genome and the Transposable Element annotations (TE), for Egg and J2 samples. $M$. incognita genome has been fragmented in silico into 500 bp bins on which histone modification enrichment was predicted with a posterior probability $>0.5$. If a histone modification was predicted, the corresponding $500 \mathrm{bp}$ bin was counted. Coverage frequencies were calculated based on $184 \mathrm{Mb}$ total $M$. incognita genome size. Three biological replicates of $M$. incognita eggs and J2s have been treated jointly to identify common histone modification enrichment using ChromstaR.

M. incognita displays canonical distribution for histone modifications

We used ChromstaR [28] to analyze the spatial pattern of statistically significant enrichment in each histone modification associated with different functional genomic elements in $M$. incognita. These associations provide clues for the functions and regulatory mechanisms of histone modifications. Spatial enrichment was calculated and represented as a heatmap for both eggs and J2s (Fig. 1 and S3 Fig, respectively). Enrichment level was calculated for all the available annotations for the $M$. incognita genome: coding sequence (CDS), exon, 5'-untranslated region (UTR), messenger RNA (mRNA), non-coding RNA (ncRNA), ribosomal RNA (rRNA), TE, 3'-UTR and tRNA.

We observed a highly significant enrichment in H3K4me3 for sequences annotated as related to proteincoding genes (CDS, exon, UTRs and mRNA) and various types of non-protein-coding RNA genes (ncRNA and tRNA), this enrichment being strongest for the 5'-UTR. An enrichment of H3K27me3 was also observed in the 5'-UTR, however the enrichment in this modification was weak for other gene-related annotations. H3K4me3 modifications were observed less frequently than expected for rRNA and TE. H3K9me3 enrichment was observed for almost all genomic annotations, particularly for TE, but not for 
levels of enrichment in $\mathrm{H} 3 \mathrm{~K} 27 \mathrm{ac}, \mathrm{H} 3 \mathrm{~K} 27 \mathrm{me} 3$ and H4K20me1 were highest for tRNA genes. A similar enrichment distribution was observed in J2s (S3 Fig).

Histone modifications associated with genomic elements were visualized on the longest scaffold, Minc3s00001, as an example (Fig. 2). For H3K4me3, sharp peaks overlapping with the transcriptional start site (TSS/5'-UTR/start) were observed. For H3K9me3, peaks overlapping both protein-coding genes and TEs were observed, whereas H3K27ac, H3K27me3 and H4K20me1 yielded broad shapes and distributions. The distribution and enrichment patterns of histone modifications suggest a canonical role of $\mathrm{H} 3 \mathrm{~K} 9 \mathrm{me} 3$ in TE repression and of H3K4me3 in promoting protein-coding gene expression (S4 Fig).

\section{Transposable element orders display preferential enrichment in $\mathrm{H} 3 \mathrm{~K} 9 \mathrm{me} 3$}

TEs are important drivers of genomic plasticity in $M$. incognita [10]. The genome-wide annotation of $M$. incognita TEs identified retrotransposons and DNA-transposons, such as terminal inverted repeats (TIR), miniature inverted repeat transposable elements (MITEs), helitrons, maverick elements, long terminal repeats (LTR), long and short interspersed nuclear elements (LINE and SINE), terminal-repeat retrotransposons in miniature (TRIM), and large retrotransposon derivatives (LARD) [10]. We calculated the frequency of histone modifications associated with TE annotations (Table 1). In both eggs and J2s, $\mathrm{H} 3 \mathrm{~K} 9 \mathrm{me} 3 \mathrm{had}$ the highest frequency, covering $8.6 \%$ and $7.1 \%$ of annotated TEs, respectively. By contrast, $\mathrm{H} 3 \mathrm{~K} 4 \mathrm{me} 3, \mathrm{H} 4 \mathrm{~K} 20 \mathrm{me} 1, \mathrm{H} 3 \mathrm{~K} 27 \mathrm{me} 3$ and H3K27ac had lower frequencies, ranging from 0.3 to $2.9 \%$. Three histone modification combinations, involving H4K20me1, were also present at a high frequency (1.4$5.9 \%$ ) at annotated TEs. The other 23 histone combinations covered less $1 \%$ of the annotated TE. We found that $\mathrm{H} 3 \mathrm{~K} 9 \mathrm{me} 3$ was observed more frequently than expected in association with all TE orders except SINE (Fig. 3). H4K20me1 modification was observed more frequently in four TE orders (TRIM, MITE, TIR and helitron). By contrast, H3K4me3, H3K27ac and H3K27me3 displayed a lower association with all TE orders. The enrichment of most TE subfamilies in H3K9me3 supports the hypothesis of a role for this histone modification in repressing TE, consistent with conservation of the canonical role of this modification in M. incognita.

\section{The H3K4me3 modification is associated with higher levels of gene expression during nematode development}

Histone modifications are known to regulate the spatiotemporal expression of protein-coding genes [29], and, thus, developmental processes. Early in the development of $M$. incognita, the transition from eggs to $\mathrm{J} 2 \mathrm{~s}$ constitutes a dramatic change in environment for the nematode, because the mobile J2s are released into the soil after hatching. We evaluated changes in both the pattern of histone modifications and gene expression during this transition, by determining the number of protein-coding genes overlapping each area of enrichment in particular histone modifications and their combinations (Table 2). We found that 13,322 of the 43,718 annotated $M$. incoanita protein-coding genes were associated with at least one Loading [MathJax]/jax/output/CommonHTML/fonts/TeX/fontdata.js 
histone modification in eggs, whereas 23,470 genes were associated with at least one histone modification in J2s. At both developmental stages, H3K4me3 modification was associated with the largest number of genes (6,014 in eggs and 10,564 in J2s), followed by H3K9me3, H4K20me1, H3K27me3 and H3K27ac. The most prevalent histone modification combinations were the H3K9me3 + H4K20me1 combination in eggs, which was associated with 531 genes, and the H3K27me3 + H4K20me1 combination in J2s, which was associated with 803 genes. 
Table 2

Distribution of histone modifications in relation to protein-coding genes.

\begin{tabular}{|c|c|c|}
\hline Histone modifications and combinations & $\begin{array}{l}\text { Associated genes in } \\
\text { eggs }\end{array}$ & $\begin{array}{l}\text { Associated genes in } \\
\text { J2s }\end{array}$ \\
\hline H3K4me3 & 6014 & 10564 \\
\hline H3K9me3 & 1762 & 3475 \\
\hline H4K20me1 & 1212 & 2127 \\
\hline H3K27me3 & 829 & 1831 \\
\hline H3К27ac & 756 & 1047 \\
\hline H3K9me3 + H4K20me1 & 531 & 699 \\
\hline H3K27me3 + H3K9me3 + H4K20me1 & 362 & 571 \\
\hline H3K27me3 + H4K20me1 & 360 & 803 \\
\hline H3K27ac + H4K20me1 & 250 & 299 \\
\hline H3K4me3 + H3K9me3 & 221 & 253 \\
\hline H3K27ac + H3K27me3 + H4K20me1 & 181 & 400 \\
\hline H3K4me3 + H4K20me1 & 150 & 221 \\
\hline $\mathrm{H} 3 \mathrm{~K} 27 \mathrm{ac}+\mathrm{H} 3 \mathrm{~K} 4 \mathrm{me} 3$ & 138 & 211 \\
\hline H3K27me3 + H3K9me3 & 96 & 220 \\
\hline H3K27ac + H3K27me3 & 93 & 166 \\
\hline H3K27ac + H3K27me3 + H3K9me3 + H4K20me1 & 66 & 92 \\
\hline H3K27ac + H3K4me3 + H4K2Ome1 & 57 & 105 \\
\hline H3K4me3 + H3K9me3 + H4K20me1 & 42 & 35 \\
\hline H3K27me3 + H3K4me3 & 41 & 66 \\
\hline $\mathrm{H} 3 \mathrm{~K} 27 \mathrm{ac}+\mathrm{H} 3 \mathrm{~K} 9 \mathrm{me} 3+\mathrm{H} 4 \mathrm{~K} 20 \mathrm{me} 1$ & 40 & 54 \\
\hline H3K27ac + H3K9me3 & 26 & 79 \\
\hline H3K27ac + H3K4me3 + H3K9me3 + H4K20me1 & 22 & 16 \\
\hline H3K27ac + H3K4me3 + H3K9me3 & 17 & 19 \\
\hline H3K27ac + H3K27me3 + H3K4me3 + H4K20me1 & 14 & 28 \\
\hline $\begin{array}{l}\mathrm{H} 3 \mathrm{~K} 27 \mathrm{ac}+\mathrm{H} 3 \mathrm{~K} 27 \mathrm{me} 3+\mathrm{H} 3 \mathrm{~K} 4 \mathrm{me} 3+\mathrm{H} 3 \mathrm{~K} 9 \mathrm{me} 3+ \\
\text { H4K2Ome1 }\end{array}$ & 13 & 22 \\
\hline Loading [MathJax]/jax/output/CommonHTML/fonts/TeX/fontdata.js & 8 & 31 \\
\hline
\end{tabular}




\begin{tabular}{|lll|}
\hline Histone modifications and combinations & $\begin{array}{l}\text { Associated genes in } \\
\text { eggs }\end{array}$ & $\begin{array}{l}\text { Associated genes in } \\
\text { J2s }\end{array}$ \\
\hline H3K27ac + H3K27me3 + H3K4me3 & 7 & 10 \\
\hline H3K27me3 + H3K4me3 + H4K2Ome1 & 5 & 8 \\
\hline H3K27me3 + H3K4me3 + H3K9me3+ H4K20me1 & 4 & 7 \\
\hline H3K27me3 + H3K4me3 + H3K9me3 & 3 & 4 \\
\hline H3K27ac+ H3K27me3 + H3K4me3 + H3K9me3 & 2 & 7 \\
\hline Total & 13322 & 23470 \\
\hline
\end{tabular}

Numbers of $M$. incognita's annotated protein-coding genes associated with H3K4me3, H3K9me3, H3K27ac, H3K27me3 and H4K20me1 histone modifications and their combinations, for Egg and J2 samples. Protein-coding genes were considered to be associated with a histone modification if at least 1 bp of the protein-coding gene annotation overlapped with the identified histone modification.

We then assessed the impact of each histone modification on gene expression (Fig. 4). According to ChIP-seq and RNA-seq data, 10,242 genes in eggs and 18,577 genes in J2s were both expressed and associated with at least one histone modification.

The distribution of gene expression values was shifted towards the highest median values for H3K4me3, and toward the lowest median values for the histone modifications H3K9me3 and H3K27me3 (Fig. 4A-B). The other two known histone modifications, H3K27ac and H4K20me1 modifications, were associated with intermediate levels of gene expression (Fig. 4A-B). These observations are consistent with observations for $C$. elegans, in which euchromatic regions with active transcription are enriched in $\mathrm{H} 3 \mathrm{~K} 4 \mathrm{me} 3$ and $\mathrm{H} 3 \mathrm{~K} 27 \mathrm{ac}$, whereas regions with low levels of transcription activity are enriched in H3K9me3 and H3K27me3 [30].

We analyzed the top and bottom $10 \%$ of protein-coding genes ranked according to expression levels, to explore the proximal regulatory elements. We extended the area of overlap considered to $2 \mathrm{~kb}$ upstream and downstream from the protein-coding genes, with ChromstaR (Fig. 5). For the top $10 \%$ of expressed genes at both stages, H3K4me3 enrichment overlapped start codon, implying that this histone modification occurs preferentially at the TSS of highly expressed genes (Fig. 5A and Fig. 5C). H3K27ac presented a "flat" profile, indicating a lack of evident enrichment. For H3K27me3, H3K9me3 and H4K20me1, the log(expected/observed) value was below zero, indicating that the most strongly expressed genes were depleted in these histone modifications. By contrast, the enrichment profile of H3K4me3 in the $10 \%$ of genes with the lowest levels of expression appeared as a "valley", indicating depletion (Fig. 5B and Fig. 5D). The H3K27ac, H3K9me3, H3K27me3 and H4K20me1 signals were flat between and around the genes (Fig. 5B and Fig. 5D). 
Finally, during the eggs-to-J2s transition, a change in the distribution of H3K4me3 was observed, with this modification disappearing from the TSS of underexpressed genes and becoming enriched at the TSS of overexpressed genes. This change in the distribution show a dynamic in histone modifications. However, it was less straightforward to establish a direct correlation between gene expression levels and the presence/absence of other histone modifications. The pattern of association between histone modifications and annotated protein-coding genes was, therefore, robust only for $\mathrm{H} 3 \mathrm{~K} 4 \mathrm{me} 3$, and was associated with an expression switch during the eggs-to-J2s transition.

\section{Stage-specific enrichment in $\mathrm{GO}$ terms for genes associated with $\mathrm{H} 3 \mathrm{~K} 4 \mathrm{me} 3$}

Given the strong association of H3K4me3 with the higher expression of protein-coding gene expression, we compared functional annotations in eggs and J2s. We identified 6,014 genes in eggs and 10,564 genes in $\mathrm{J} 2 \mathrm{~s}$ as associated with $\mathrm{H} 3 \mathrm{~K} 4 \mathrm{me}$. We then annotated the corresponding $M$. incognita proteins thanks to Interproscan [21]. Enrichment was detected for $46 \mathrm{GO}$ terms in eggs and $8 \mathrm{GO}$ terms in $\mathrm{J} 2 \mathrm{~s}$ (Fig. 6). GO terms such as "ribonucleoside- and nucleoside-associated processes" were associated with the egg stage, whereas compounds identified in the metabolic processes' ontology such as "ether", "citrate" and "tricarboxylic acid" were specifically enriched in the J2 stage. We also identified $40 \mathrm{GO}$ terms as displaying enrichment at both stages, with the strongest enrichment observed for processes related to protein biosynthesis: "translation", "peptide biosynthetic process", "peptide metabolic process", "amide biosynthetic process", "cellular amide metabolic process" (Fig. 6).

Our observations of H3K4me3 dynamics during the eggs-to-J2s transition led us to analyze the functions of the products of the differentially expressed genes. We identified 89 genes in eggs and 177 genes in $\mathrm{J} 2 \mathrm{~s}$ as both associated with $\mathrm{H} 3 \mathrm{~K} 4 \mathrm{me} 3$ and differentially expressed. Overrepresentation was detected for 39 GO terms specific to eggs (56/89 genes), and 9 GO terms specific to J2s (28/177 genes). GO terms linked to genomic organization and cell cycle-associated processes were associated with the egg stage, whereas cell signaling, and stimulus responses were specific to the J2 stage (Fig. 7).

The identification of orthologs in $C$. elegans and parasitic nematodes provided insight into the functions of the H3K4me3-associated genes differentially expressed during the eggs-to-J2s transition. We found 63 genes in M. incognita eggs and 119 genes in J2s for which at least one ortholog was present in $C$. elegans. Interestingly, orthologs of genes linked to the regulation of histones, DNA metabolism, cytoskeleton organization and the mitotic checkpoint were overrepresented among the most expressed genes in $M$. incognita eggs (Table S2). In M. incognita J2s, we identified orthologous genes involved in redox status and the regulation of cell trafficking (Table S3).

\section{RKN effector-coding genes are subject to regulation by histone modifications}

Effectors are secreted proteins that are essentials to nematode parasitism. Studies using RNA-Seq 
and an opportunity to characterize their different patterns on infective aptitude, from the penetration to the successful interaction leading to feeding sites and the production of the next generation of eggs [31, 32]. In M. incognita, subventral glands (SvG) are mostly active during the earliest steps, whereas dorsal gland (DG) is active in the latest steps of the infection. A total of 48 and 34 putative non-redundant $M$. incognita effectors have been identified in SvG and DG, respectively [31]. We looked for histone modification associated with effector genes that are overexpressed in J2s. Among the $48 \mathrm{SvG}$ effectors, 14 were associated with both a histone modification dynamic and a differential expression pattern during eggs-to-J2s transition. Only two of those effectors, Mi-GSTS1 and msp2, showed an appearance of activating histone modification in J2s. In contrast, combinations of histone modifications involving the repressive modifications $\mathrm{H} 3 \mathrm{~K} 27 \mathrm{me} 3$ and $\mathrm{H} 3 \mathrm{~K} 9 \mathrm{me} 3$ appeared to be the most abundant in this class of effectors (Table 3, S4 Table). Among the 34 DG effectors, 4 were associated with both a histone modification dynamic and a differential expression pattern during eggs-to-J2s transition. All of them were associated with combinations of repressive histone modifications (Table 4, S5 Table). Interestingly, the Mi-14-3-3-b DG effector exhibits reverse dynamics during the transition from eggs to J2s with a repression of expression in $\mathrm{J} 2 \mathrm{~s}$ associated with the appearance of H3K27me3. Altogether, these results suggest that histone modifications act as crucial regulators to precisely produce some effectors in a dose manner and in temporal sequence during parasitism. 
Table 3

Transcriptional regulation of known subventral glands (SvG) effector genes.

\begin{tabular}{|c|c|c|c|c|c|}
\hline $\begin{array}{l}\text { Gene } \\
\text { numbers } \\
\text { according } \\
\text { to Da } \\
\text { Rocha et } \\
\text { al., } 2021\end{array}$ & $\begin{array}{l}\text { Gene names } \\
\text { according to } \\
\text { literature }\end{array}$ & $\begin{array}{l}\text { Log2(Fold- } \\
\text { change } \\
\text { J2s/Eggs) }\end{array}$ & Gene & HPTM_eggs & HPTM_J2s \\
\hline \multicolumn{6}{|c|}{ Effector genes associated with a differential expression level during eggs-to-J2s transition } \\
\hline 7 & $31 \mathrm{H} 06$ (msp22) & 3.57 & Minc3s00376g11251 & ] & [] \\
\hline 47 & $\begin{array}{l}\text { SXP-RAL2 = Mi- } \\
\text { SXP-1 }\end{array}$ & 4.08 & Minc3s00381g11354 & ] & [] \\
\hline 27 & Mi-PG1 & 5.59 & Minc3s00007g00481 & ] & [] \\
\hline 2 & 2B02B (Mi-PEL2) & 6.12 & Minc3s00094g04359 & ] & [] \\
\hline 26 & Mi-PEL2 & 6.40 & Minc3s00566g14364 & ] & [] \\
\hline 35 & Minc03325 & 7.55 & Minc3s00020g01295 & ] & [] \\
\hline 21 & $\begin{array}{l}\text { CL5Contig2_1- } \\
\text { EST (Sec-2) }\end{array}$ & 2.30 & Minc3s00113g04971 & [H3K4me3] & [H3K4me3] \\
\hline 33 & Minc01696 & 4.48 & Minc3s00036g02098 & [H3K9me3] & [H3K9me3] \\
\hline
\end{tabular}

Effector genes associated with both a histone modification dynamic and a differential expression level during eggs-to-J2s transition

\begin{tabular}{|c|c|c|c|c|c|}
\hline 25 & Mi-GSTS1 & 2.14 & Minc3s00365g11068 & [ & [H3K4me3] \\
\hline 6 & 30H07 (msp20) & 2.95 & Minc3s05190g37766 & ] & $\begin{array}{l}\text { [H3K27ac + } \\
\text { H3K27me3 } \\
+ \\
\text { H4K20me1] }\end{array}$ \\
\hline 13 & 8D05 (msp9) & 3.20 & Minc3s01244g22037 & ] & [H3K9me3] \\
\hline 18 & $\begin{array}{l}\text { CL312Contig1_1- } \\
\text { EST }\end{array}$ & 3.90 & Minc3s00070g03486 & $\begin{array}{l}{[\mathrm{H} 3 \mathrm{~K} 4 \mathrm{me} 3} \\
+ \\
\mathrm{H} 4 \mathrm{~K} 20 \mathrm{me} 1]\end{array}$ & [H3K4me3] \\
\hline 3 & 2G02 (msp2) & 3.96 & Minc3s00855g18130 & ] & [H4K20me1] \\
\hline 14 & 8E08B (Eng4) & 5.04 & Minc3s00139g05823 & ] & [H3K9me3] \\
\hline 48 & Mi-PEL1 & 6.09 & Minc3s00441g12378 & ] & [H3K27me3] \\
\hline 8 & 34C04 (Mi-PL1) & 6.14 & Minc3s01107g20785 & [H4K20me1] & [H3K27me3] \\
\hline 29 & Mi-VAP2 & 6.33 & Minc3s01051g20218 & ] & $\begin{array}{l}\text { [H3K27ac + } \\
\text { H3K27me3 } \\
+ \\
\text { H4K20me1] }\end{array}$ \\
\hline
\end{tabular}




\begin{tabular}{|c|c|c|c|c|c|}
\hline $\begin{array}{l}\text { Gene } \\
\text { numbers } \\
\text { according } \\
\text { to Da } \\
\text { Rocha et } \\
\text { al., } 2021\end{array}$ & $\begin{array}{l}\text { Gene names } \\
\text { according to } \\
\text { literature }\end{array}$ & $\begin{array}{l}\text { Log2(Fold- } \\
\text { change } \\
\text { J2s/Eggs) }\end{array}$ & Gene & HPTM_eggs & HPTM_J2s \\
\hline 23 & $\begin{array}{l}\text { Mi-CBP1 } \\
(42 \mathrm{G} 06)\end{array}$ & 6.51 & Minc3s00139g05824 & [H3K27me3] & [H3K9me3] \\
\hline 43 & Minc13292 & 6.99 & Minc3s00083g03979 & [H3K9me3] & [] \\
\hline 10 & $\begin{array}{l}\text { 5A12B (ENG1, } \\
\text { ENG3) }\end{array}$ & 8.51 & Minc3s03138g32920 & [] & $\begin{array}{l}{[\mathrm{H} 3 \mathrm{~K} 27 \mathrm{ac}+} \\
\mathrm{H} 3 \mathrm{~K} 27 \mathrm{me} 3 \\
+ \\
\text { H4K20me1] }\end{array}$ \\
\hline 24 & $\begin{array}{l}\text { Mi-ENG1 } \\
(1 \mathrm{C} 11 \mathrm{~B})\end{array}$ & 8.53 & Minc3s03136g32914 & [ & $\begin{array}{l}\text { [H3K27me3 } \\
+ \\
\text { H4K20me1] }\end{array}$ \\
\hline 37 & Minc03866 & 8.67 & Minc3s00066g03327 & $\begin{array}{l}\text { [H3K27me3 } \\
+\mathrm{H} 3 \mathrm{~K} 9 \mathrm{me} 3 \\
+ \\
\text { H4K20me1] }\end{array}$ & [H3K9me3] \\
\hline
\end{tabular}

According to the literature [31], 48 non-redundant $M$. incognita effectors have been identified in SvG (i.e., columns: effector-gene number, gene name and accession number on $M$. incognita genome). For this study, SvG effector genes were classified according to both their expression level and flanking histone modifications during eggs-to-J2s transition. Differential gene expression is shown as RNA-seq fold expression changes, Log2(Fold Change), calculated using DESeq2 on triplicates, with a p value $<0.05$ as a threshold for overexpression. Effector genes were considered to be associated with a histone modification if at least $1 \mathrm{bp}$ of the annotation overlapped with an identified histone modification. Three biological replicates of $M$. incognita eggs and J2s have been treated jointly to identify common histone modification enrichment using ChromstaR. [] indicates no histone modification has been identified. 
Table 4

Transcriptional regulation of known dorsal gland (DG) effector genes.

$\begin{array}{llllll}\begin{array}{l}\text { Gene } \\ \text { numbers }\end{array} & \begin{array}{l}\text { Gene } \\ \text { names }\end{array} & \begin{array}{l}\text { Log2(Fold- } \\ \text { change }\end{array} & \text { Gene } & \text { HPTM_egg } & \text { HPTM_juvenile } \\ \text { according } & \begin{array}{l}\text { according } \\ \text { to Da }\end{array} & \begin{array}{l}\text { J2s/Eggs) } \\ \text { to literature }\end{array} & & & \\ \text { Rocha et al., } & & & & \\ 2021 & & & & \end{array}$

Effector genes associated with a differential expression level during eggs-to-J2s transition

\begin{tabular}{|c|c|c|c|c|c|}
\hline 28 & Minc12639 & 3.18 & Minc3s00340g10545 & [] & [] \\
\hline 25 & Minc01595 & 3.90 & Minc3s01184g21493 & $\begin{array}{l}{[\mathrm{H} 3 \mathrm{~K} 27 \mathrm{me} 3} \\
+ \\
\mathrm{H} 4 \mathrm{~K} 20 \mathrm{me} 1]\end{array}$ & $\begin{array}{l}\text { [H3K27me3 + } \\
\text { H4K20me1] }\end{array}$ \\
\hline
\end{tabular}

Effector genes associated with both a histone modification dynamic and a differential expression level during eggs-to-J2s transition

\begin{tabular}{|c|c|c|c|c|c|}
\hline 12 & $\begin{array}{l}34 \mathrm{F06} \\
(\mathrm{msp} 24)\end{array}$ & 2.68 & Minc3s00321g10151 & [H3K27me3] & $\begin{array}{l}\text { [H3K27me3 + } \\
\text { H3K9me3] }\end{array}$ \\
\hline 26 & $\begin{array}{l}\text { Minc02097 } \\
\text { (35A02, } \\
\text { msp25) }\end{array}$ & 4.80 & Minc3s00202g07465 & [] & [H3K27me3] \\
\hline 9 & $\begin{array}{l}\text { 25B10 } \\
\text { (msp33) }\end{array}$ & 4.99 & Minc3s03649g34419 & [] & [H3K9me3] \\
\hline 16 & $\begin{array}{l}\text { 6F06 } \\
\text { (msp4) }\end{array}$ & 5.65 & Minc3s02324g29465 & [H3K9me3] & ] \\
\hline 23 & Mi-14-3-3 & -3.43 & Minc3s00122g05244 & [] & [H3K27me3] \\
\hline \multicolumn{6}{|c|}{$\begin{array}{l}\text { According to the literature [31], } 34 \text { non-redundant } M \text {. incognita effectors have been identified in DG } \\
\text { (i.e., columns: effector-gene number, gene name and accession number on } M \text {. incognita genome). For } \\
\text { this study, DG effector genes were classified according to both their expression level and flanking } \\
\text { histone modifications during eggs-to-J2s transition. Differential gene expression is shown as RNA-seq } \\
\text { fold expression changes, Log2(Fold Change), calculated using DESeq2 on triplicates, with a p value < } \\
0.05 \text { as a threshold for overexpression. Effector genes were considered to be associated with a } \\
\text { histone modification if at least } 1 \text { bp of the annotation overlapped with an identified histone } \\
\text { modification. Three biological replicates of } M \text {. incognita eggs and J2s have been treated jointly to } \\
\text { identify common histone modification enrichment using ChromstaR. [] indicates no histone } \\
\text { modification has been identified. }\end{array}$} \\
\hline
\end{tabular}

\section{Discussion}

Many biological processes involve chromatin changes, including the delimitation of functional elements in the genome and transcription regulation, particularly during complex parasitic life cycles. The RKN $M$. incognita has a wide host range and is found worldwide. Despite its clonal reproduction, $M$. incognita can rapidly adapt to unfavorable conditions $[7,8]$. Epigenetic mechanisms may contribute to this rapid adaptation and the parasitic success of this nematode. Cytosine methylation is absent, or present at only Loading [MathJax]/jax/output/CommonHTML/fonts/TeX/fontdata.js is no genes encoding DNA methyltransferases 
$[20,21]$. Conversely, histone (de)acetylation and (de)methylation enzymes are present and conserved in the genome of $M$. incognita [21]. However, the role of histone modifications in phytoparasitic nematode biology remains unknown. We deciphered the chromatin landscape in the RKN $M$. incognita by studying five histone modifications and analyzing their dynamics during development. These modifications were not randomly distributed in $M$. incognita and colocalized with genomic elements, forming specific epigenetic signatures.

In the model nematode $C$. elegans, $\mathrm{H} 3 \mathrm{~K} 4 \mathrm{me} 3$ enrichment is observed in actively expressed regions and therefore associated with euchromatin. By contrast, H3K9me3 and H3K27me3 enrichment is observed in silent genes, transposons, and other repetitive sequences and as such associated with heterochromatic regions. This histone code is observed in most organisms [33, 34]. However, these histone modifications do not have the same biological implications in some organisms [35]. H3K4me3 activates gene expression by a charge-mediated decompaction of the chromatin at promoter sequences [36]. H3K4me3 is usually distinguished by sharp peaks or enrichment around the TSS [37]. In $M$. incognita, we observed a typical profile of this type, with the sharp H3K4me3 peaks overlapping with the TSS of annotated protein-coding genes, associated with higher levels of gene expression. The conservation of the canonical function of $\mathrm{H} 3 \mathrm{~K} 4 \mathrm{me} 3$ in $M$. incognita will pave the way for deciphering transcriptional regulation during development and parasitism.

Another activating histone modification, H4K20me1, typically results in diffuse chromatin modifications [38]. In M. incognita, H4K20me1 displayed a diffuse profile of this type over the entire genome and was associated with higher levels of expression than the repressive histone modifications. H4K20me1 levels have been shown to change dynamically during the cell cycle, peaking during the G2/M phase [39]. At the whole-organism scale, dynamic changes in H4K20 methylation have been observed during mouse preimplantation development, with this modification playing a key role in the maintenance of genome integrity [40]. M. incognita seems to have the same histone modification machinery as model organisms, and we can, therefore, predict analogous functions for H4K20me1 in cell cycle regulation and the maintenance of genome integrity in this nematode.

Another well-described histone modification is the heterochromatin-associated modification H3K9me3 [41], which plays an important role in regulating gene expression [42] and is characterized by distinct peaks at protein-coding genes [43]. $\mathrm{H} 3 \mathrm{~K} 9 \mathrm{me} 3$ is also associated with TEs, which require controlled repression to prevent chaotic transposition in the genome. This modification has been described as the principal regulator of these elements in mouse embryonic stem cells [43] and in C. elegans [33]. In $M$. incognita, $\mathrm{H} 3 \mathrm{~K} 9 \mathrm{me} 3$ presented sharp peaks in the bodies of genes with low levels of expression relative to other histone modifications. Moreover, the majority of H3K9me3 modifications were found on annotated TE, suggesting that $\mathrm{H} 3 \mathrm{~K} 9 \mathrm{me} 3$ represses the mobile elements of the genome and indicating that its canonical function is also conserved in M. incognita.

Different sets of histone modifications can account for gene expression [44]. For instance, a balance hotween $\mathrm{H} 3 \mathrm{~K} 27$ trimethvlation and $\mathrm{H} 2 \mathrm{~K} 27$ aretvlation has been shown to regulate gene expression in a Loading [MathJax]/jax/output/CommonHTML/fonts/TeX/fontdata.js

Page $19 / 40$ 
dynamic manner [45]. H3K27me3 is a broadly distributed repressive histone modification that downregulates gene expression, as demonstrated during development and cell differentiation [46, 47]. By contrast, $\mathrm{H} 3 \mathrm{~K} 27 \mathrm{ac}$ is an activating histone modification that may be broadly distributed [48] or display narrow peaks [49]. In M. incognita, H3K27me3 and H3K27ac were broadly distributed throughout the genome despite their dual effects. H3K27ac is usually found on enhancers and can be used to distinguish between active and poised enhancers [50]. H3K27ac was associated with genes displaying higher levels of expression than those associated with repressive modifications in $M$. incognita. As in mammals, studies of H3K27ac enrichment could potentially be used to predict enhancers in $M$. incognita on the basis of local chromatin structure. Other sets of histone modifications may fine-tune regulation of the chromatin landscape, but their identification was limited by antibody availability and specificity in $M$. incognita.

Different combinations of histone modifications can be colocalized, acting together as activators, repressors or in a bivalent manner [51]. For instance, gene expression levels have been shown to be regulated by the ratio of $\mathrm{H} 3 \mathrm{~K} 27 \mathrm{Me} 3$ to $\mathrm{H} 3 \mathrm{~K} 4 \mathrm{Me} 3$ modifications, leading to a bivalent outcome: repression or activation [51]. In M. incognita, H3K27me3 enrichment was observed at the 5'UTR, potentially accounting for the low levels of expression for the associated genes. The colocalization of H3K27me3 and H3K4me3 at the 5' UTR suggests bivalency for these two modifications in $M$. incognita. H3K27me3 enrichment was also found within tRNA-genes, suggesting a role for this modification in tRNA regulation, consistent with the presence of H3K27me3 near the RNA polymerase III binding sites used for the synthesis of tRNA in human embryonic stem cells [52].

Our findings indicate that histone modification is conserved in $M$. incognita and defines a reproducible and consistent landscape. We therefore further investigated the dynamics of histone modifications during development and parasitism, by considering the egg and juvenile stages. This developmental transition constitutes a major change in the nematode environment. J2s hatch and are released into the soil, in which they begin their life as mobile entities, moving towards the plant roots. The soil is a radically different environment from the eggs, and the newly hatched J2s must therefore adapt very rapidly to this new environment. At the scale of the genome, we found that the histone modification profile and gene expression level remained relatively stable during development. However, dynamical changes were highlighted during the eggs-to-J2s transition in M. incognita, in analyses at gene level. We identified pathways relating to the cell cycle as overrepresented in eggs, promoting $M$. incognita development. By contrast, J2s presented pathways linked to stimulus responses, reflecting the needs of J2s following their release into the soil after hatching, consistent with previous observations [31]. Furthermore, based on $C$. elegans orthology, egg stage-specific genes were involved in cell division, whereas J2s-specific genes were mainly involved in redox status regulation, reflecting the environment shift during the $M$. incognita life cycle. The identification of such candidate genes in $M$. incognita highlights the involvement of histone modifications in nematode development and could lead to the identification of new targets for pest control. 
Histone modifications also contribute to the parasitic success of many animal or plant parasites. Parasites possess an arsenal of molecules known as effectors, which promote infection success. Fungal species, such as Fusarium graminearum or Leptosphaeria maculans, are the principal plant-parasitic organisms displaying chromatin-based control of concerted effector gene expression at specific times during infection [53, 54]. In Zymoseptoria tritici, the H3K27me3 distribution dictates effector gene expression during host colonization, preventing the expression of these genes when not required [55].

The association of J2s-overexpressed effector-coding genes with histone modifications suggests that epigenetic regulation contributes to $M$. incognita parasitism. However, by contrast to what we observed for stage-specific genes, the overexpression of effectors in J2s was not associated with H3K4me3, whatever the secretory gland, SvG and DG. For effectors, overexpression in J2s is mainly associated with combinations of repressive histone modifications. The overexpression of effector-coding genes needed at a specific time point, such as cell wall degrading enzymes during juvenile stage which help to the penetration of the nematode into the root system, may be under strong and complex regulation. In that respect, having effector-coding genes under repressive histone modifications could help the nematode to fine-tune their expression in a spatio-temporal way during plant infection. For instance, different histone modification dynamics may account for the coordinated, yet slightly different, expression of 2 pectate lyase genes, Mi-pel-1, and Mi-pel-2, during $M$. incognita infection of roots. Indeed, while these 2 genes were both overexpressed in early J2s stage (with similar fold-changes), only Mi-pel-1 gene was associated with repressive H3K27me3. Potential release of this repressive histone modification may provide an explanation for the expression of Mi-pel-1 only at late $\mathrm{J} 2 \mathrm{~s}$ stage, as previously reported [56].

Another example is the Mi-14-3-3-b DG effector gene which was the only one overexpressed in eggs and showing appearance of a H3K27me3 modification during the eggs-to-J2s transition. This result correlates with what is already known about the expression pattern of Mi-14-3-3-b during $M$. incognita infection with an early expression in eggs, a strong repression in J2s and a late expression in the female stage [57].

More generally, these results suggest that the fine-tuning of effector production during parasitism could be achieved through either another activating histone modification, still to be studied, or a different process such as transcription factors (TFs) activation. Consistent with this, a putative cis-regulatory element "Mel-DOG" has been identified in M. incognita DG effector promoters [31]. This might be the missing activator switch for the expression of DG effector genes at specific stages during the lifecycle of the nematode, even if the associated TFs are yet to be discovered. To achieve precise and accurate regulation of effector-genes, TFs and histones modifications may work in a cooperative way.

\section{Conclusions}

We describe here the chromatin landscape of a parasitic nematode, revealing a dynamic process during the life cycle. This pioneering study shows that $M$. incognita presents a histone modification similar to that of the model nematode $C$. elegans. Beyond model organisms, the epigenome arguably plays an 
important role in development and the regulation of parasitism. The next step will be to decipher the epigenetic response of $M$. incognita to environmental changes, such as host adaptation, in greater detail.

\section{Methods}

\section{Biological materials}

One-month-old tomato plants, Solanum lycopersicum (St Pierre), were inoculated with soil infested with M. incognita. Eggs were collected from tomato roots seven-week-old after infection, by grinding, sterilizing, and filtering, as previously described [58]. Extracted eggs were purified by centrifugation on a $30 \%$ sucrose gradient, washed and either stored at $-80^{\circ} \mathrm{C}$ for subsequent experiments or kept in autoclaved tap water, at room temperature, for seven days, to produce juveniles J2s. Hatched J2s were collected by filtration and centrifugation $(13,000 \times \mathrm{g}, 1 \mathrm{~min})$ and stored at $-80^{\circ} \mathrm{C}$.

\section{Antibody screening}

Commercially available antibodies raised against histones with posttranslational modifications were selected on the basis of two criteria: ChIP-grade and preferentially used in the model nematode $C$. elegans (Table S1). We assessed the specificity of each antibody in $M$. incognita by a two-step method combining western blotting and ChIP-titration, as described by Cosseau [26].

\section{Western blot}

Nematodes were resuspended in a homemade extraction buffer (3\% SDS, $10 \%$ sucrose, 0.2 M DTT, 1.25 $\mathrm{mM}$ sodium butyrate, and $62.5 \mathrm{M}$ Tris/Cl pH 6.8) and crushed with a glass Dounce homogenizer for 2 minutes. Samples were sonicated (Vibra Cell ${ }^{\mathrm{TM}}$ ) three times, at $70 \%$ intensity, for $15 \mathrm{~s}$ each, with cooling on ice during the intervals. They were then boiled for 5 minutes at $99^{\circ} \mathrm{C}$ after the addition of Laemmli buffer (Cat. \#1410737, Biorad). Proteins were separated by SDS-PAGE and transferred to a membrane with a Trans Blot TURBO (Biorad). The membrane was incubated for $1 \mathrm{~h}$ at $37^{\circ} \mathrm{C}$ in a homemade blocking buffer ( $50 \mathrm{mM} \mathrm{NaCl}, 0.05 \%$ Tween 20, 5\% fat-free dry milk, $20 \mathrm{mM}$ Tris/Cl pH 7) and then for 1.5 hours with antibodies in the blocking buffer. Finally, the membrane was washed and incubated with a secondary antibody. Signals were detected by incubation with SuperSignal West Pico Chemiluminescent Substrate (Thermo Fisher Scientific, Cat.34579) and to the use of ChemiDoc Imaging systems (Biorad). Antibodies that did not bind to a unique target were discarded from the analysis (S1 Table and S1 Fig).

\section{Crosslinking and chromatin immunoprecipitation (ChIP)}

Frozen eggs or juveniles were resuspended in $500 \mu \mathrm{L}$ Hank's balanced salt solution (HBSS, Sigma-Aldrich, Cat. \#H4641, Lot RNBG1861) and crushed with a glass Dounce homogenizer for $7 \mathrm{~min}$. We then added $500 \mu \mathrm{L} 1 \mathrm{x}$ HBSS and transferred the solution to an Eppendorf tube. Samples were centrifuged (at 2,700 $\mathrm{x}$ $\mathrm{g}, 5 \mathrm{~min}, 4^{\circ} \mathrm{C}$ ). For crosslinking, the pellet was resuspended in $1 \mathrm{~mL} 1 \times$ HBSS containing $13.5 \mu \mathrm{L}$ of $37 \%$ formaldehyde (Sigma-Aldrich, Cat. \#252549), and incubated for $10 \mathrm{~min}$ at room temperature, with occasional inversion. Bindina was stopped bv addina $57 \mu \mathrm{L} 2 \mathrm{M}$ glycine (Diagenode, cat. C01011000) Loading [MathJax]/jax/output/CommonHTML/fonts/TeX/fontdata.js 
and incubating the sample for $5 \mathrm{~min}$ at room temperature. Samples were centrifuged at $2,700 \times \mathrm{g}, 4^{\circ} \mathrm{C}$ for $5 \mathrm{~min}$. The pellet was rinsed twice, with $1 \mathrm{~mL} 1 \times$ HBSS each, and centrifuged again $\left(2,700 \times g, 4^{\circ} \mathrm{C}\right.$ for 5 min). ChIP was performed with the Auto-Chipmentation Kit for histones (Diagenode, cat. C01011000). Crosslinked chromatin was resuspended in $100 \mu \mathrm{L}$ cold lysis buffer IL1 and incubated at $4^{\circ} \mathrm{C}$ for $10 \mathrm{~min}$ in a rotating well. Following centrifugation $\left(2,700 \times \mathrm{g}, 4^{\circ} \mathrm{C}\right.$ for $\left.5 \mathrm{~min}\right)$, the supernatant was discarded, and the pellet was resuspended in $100 \mu \mathrm{L}$ cold lysis buffer IL2, and incubated in a rotating well for $10 \mathrm{~min}$ at $4^{\circ} \mathrm{C}$. The suspension was centrifuged $\left(2,700 \times \mathrm{g}, 4^{\circ} \mathrm{C}\right.$ for $\left.5 \mathrm{~min}\right)$ and the pellet was resuspended in $100 \mu \mathrm{L}$ of complete shearing buffer iS1. Samples were sonicated with the Bioruptor Pico, over 5 cycles (30 s ON and $30 \mathrm{~s}$ OFF). They were then transferred to new tubes and centrifuged $\left(16,000 \times g, 10 \mathrm{~min}, 4^{\circ} \mathrm{C}\right)$. The supernatants were transferred to new tubes, pooled by batch and $500 \mu \mathrm{L}$ iS1 was added. The ChIPmentation program was selected on the Diagenode SX-8G IP-Star Compact. We used the following parameters: 3 hours of antibody coating at $4^{\circ} \mathrm{C}, 13$ hours of IP reaction at $4^{\circ} \mathrm{C}, 10 \mathrm{~min}$ wash at $4^{\circ} \mathrm{C}$ and 5 min tagmentation. All steps were performed with the intermediate mixing speed.

ChIP-buffer, antibody coating mix and immunoprecipitation mix were prepared in accordance with the supplied protocol. Stripping, end repair and reverse cross-linking were performed with the reagents provided with the kit.

\section{Titration by qPCR}

The immunoprecipitated DNA was quantified by qPCR with a LightCycler480 (Roche System). The PCR mix was prepared with $2 \mu \mathrm{L}$ of immunoprecipitated chromatin, in a final volume of $10 \mu \mathrm{L}(0.5 \mu \mathrm{L}$ of each primer, $5 \mu \mathrm{L}$ of Eurogentec Takyon ${ }^{\text {TM }}$ SYBR ${ }^{\circledR} 2 \times$ qPCR Mastermix Blue). The following Light-Cycler run protocol was used: denaturation at $95^{\circ} \mathrm{C}$ for $3 \mathrm{~min}$; amplification and quantification ( 40 cycles), $95^{\circ} \mathrm{C}$ for $30 \mathrm{~s}, 60^{\circ} \mathrm{C}$ for $30 \mathrm{~s}, 72^{\circ} \mathrm{C}$ for $30 \mathrm{~s}$. Cycle threshold (Ct) was determined with the fit point method of LightCycler480 version 1.5. PCR was performed in triplicate, and the mean Ct was calculated.

Percent input recovery (\%IR) was calculated as described by Cosseau [26], with the following formula:

$\% I R=100\left(E^{C t}\right.$ ( input) $-C t$ (IPbound $\left.)\right)$ where $\mathrm{E}$ is primer efficiency, $\mathrm{Ct}($ input $)$ is the $\mathrm{Ct}$ of the unbound fraction, and $\mathrm{Ct}(\mathrm{IPbound})$ is the $\mathrm{Ct}$ of the immunoprecipitated sample. Only antibodies reaching saturation were considered specific and were used for ChIP-Seq experiments, at their optimal concentration (S1 Table and S1 Fig).

\section{ChIP-Seq}

The same ChIP protocol was performed with the Auto-Chipmentation kit for histones (Diagenode,cat. C01011000), with specific antibodies validated for M. incognita, targeting the histone modifications H3K4me3 (Merck Millipore ref 04-745, batch 2452485), H3K9me3 (Abcam ref ab8898, batch GR3064022), H3K27ac (Abcam ref ab4729, batch GR150367-2), H3K27me3 (Epigentek ref A-4039, batch 503019) and H4K20me1 (Abcam ref ab9051, batch GR158874-1). For each antibody, ChIP was performed in biological triplicate on two different $M$. incognita stages: eggs and J2s. The ChIP control was the input- 
Illumina libraries were constructed with primer indices provided by the Auto-Chipmentation kit for histones (Diagenode,cat. C01011000), according to the protocols supplied. The amount of DNA was determined and adjusted by qPCR quantification. Amplified libraries were quantified on a Bioanalyzer and sequenced by the BioEnvironnement platform (University of Perpignan, France) with an Illumina NextSeq 550 instrument generating 75 bp single-end reads. Sequencing reads have been deposited in the NCBI Sequence Read Archive (SRA, NCBI), under accession number PRJNA725801.

\section{ChIP-Seq data analysis}

Graphical representations were generated, and statistical analyses were performed with $\mathrm{R}$ version 3.6.1 (www.r-project.org) and the following libraries: chromstaR, cowplot, bamsignals, gplots, reshape2, tidyverse, ggpubr and rstatix.

Illumina read quality was analyzed with FastQC [60]. Read trimming was performed with Trim Galore (http://www.bioinformatics.babraham.ac.uk/projects/trim_galore/), using the default parameters. Processed reads were mapped onto the reference genome of $M$. incognita [27] with Bowtie2, using "Very sensitive end-to-end" presets [61]. All library sizes were downsampled to the size of the smallest library we had, corresponding to 3.7 million reads.

Peak calling for domain visualization in the $M$. incognita genome was performed with Peakranger [62]. A fraction of sheared chromatin without immunoprecipitation has been used as input to subtract the background level. Normalized tracks were visualized with the Integrative Genome Viewer [63]. Biological replicates were treated independently, and reproducibility was checked manually (S2 Fig).

Enriched domain identification and chromatin state analysis were performed with ChromstaR, using the differential mode with default parameters, except for bin size and step size, which were set at 500 bp and 250 bp, respectively [28]. ChromstaR uses a hidden Markov model approach to predict domains displaying enrichment. The three biological replicates were treated jointly by ChromstaR to generate the HMM model. Peak prediction for each histone modification was defined by a posterior probability $>0.5$.

The genomic frequencies of the histone modifications were calculated with ChromstaR and correspond to the percentage of bin sizes ( $500 \mathrm{bp})$ with histone modifications and their combinations (defined as the overlapping of multiple modifications on the same bin) over the $184 \mathrm{Mb}$ of the $M$. incognita genome. As an example, H3K4me3 frequency (\%) corresponds to the total covered bases ( 25MB) divided by the genome size ( 184MB) and multiplied by 100.

Analyses of enrichment at genomic elements were performed by plotting ChromstaR heatmaps. Heatmaps were generated from the logarithm(observed/expected) ratio. The "expected" parameter corresponds to the probability of a bin to be both a genomic element and marked with histone modification at the same location. The "observed" parameter constitutes the frequency of a bin corresnondina to he hoth a cenomic. element and marked with histone modification at the same location. Loading [MathJax]/jax/output/CommonHTML/fonts/TeX/fontdata.js

Page 24/40 
When the ratio is $>0$, the genomic element is observed mor frequently than expected and considered as statistically enriched with the histone modification. We used genome annotation data from a previous genome sequencing analysis of $M$. incognita, including 43,718 protein-coding genes (corresponding to mRNA annotation) [27]. Furthermore, canonical TEs were annotated and filtered using REPET $[10,60]$.

Regions of differential enrichment were determined with a minimum differential posterior, to detect pairwise differences at $p=0.9999$.

\section{Transcription analysis and histone modification profile}

RNA-seq data were provided by previous analyses of different life stages, eggs and J2s, of the nematode [27]. Data was reprocessed by Kozlowski and coworkers [10], to generate FPKM values. Raw FPKM values were transformed to obtain Log(median FPKM+1) values, keeping the median of the three biological replicates as a representative value. Raw FPKM values are available online [64]. The number of genes associated with histone modifications was calculated by determining whether the gene position overlapped a position of histone modification enrichment by at least $1 \mathrm{bp}$. A boxplot representing the levels of gene expression associated with the five histone modifications was generated for genes for which expression data were available. A Kruskal-Wallis test was performed, followed by a pairwise Dunn test, to identify significant differences in gene expression level between different histone modifications, with a $p$ value $<0.05$ was considered significant.

The mean enrichment profiles were calculated by ChromstaR, based on the log(expected/observed) enrichment from $2 \mathrm{~kb}$ upstream to $2 \mathrm{~kb}$ downstream from the protein-coding genes, considering only the top and bottom $10 \%$ of genes ranked according to expression level associated with the five histone modifications.

Differentially expressed genes were identified using previous RNA-seq data $[27,65]$ processed by DE-seq2 [66], a $p$ value $<0.05$ was considered significant and a fold-change $>2$ for overexpression.

\section{GO enrichment analysis}

GO term enrichment was analyzed with the R package GOfuncR, using default parameters. The FWER cutoff was set at 0.05 to identify overrepresented GO terms. (-) (pvalue) was calculated for the representation of GO terms, more specifically "Biological Processes". All M. incognita genes associated with GO terms were used as references for GO enrichment analysis (i) for genes associated with H3K4me3 only; and (ii) for genes both associated with H3K4me3 only and differentially expressed during eggs-to-J2s transition.

M. incognita orthologs were identified from a previous work [21] using FamilyCompanion to identify orthologous links with 20 other species. Searches for GO terms for $C$. elegans orthologs were performed Loading [MathJax]/jax/output/CommonHTML/fonts/TeX/fontdata.js R webtool [67]. 


\section{Declarations}

\section{Ethics approval and consent to participate}

Not applicable

Consent for publication

Not applicable

\section{Availability of data and materials}

The datasets generated and analysed during the current study are available in the NCBI Sequence Read Archive (SRA, NCBI), under accession number PRJNA725801.

\section{Competing interests}

The authors declare that they have no competing interests.

\section{Funding}

This work was supported by INRAE and the French Government (National Research Agency, ANR) through the ANR-18-CE20-0002 (ADMIRE), LABEX SIGNALIFE ANR-11-LABX-0028 and IDEX UCAJedi ANR-15-IDEX0 programs. With the support of LabEx CeMEB, an ANR « Investissements d'avenir » program (ANR-10LABX-04-01). This study is set within the framework of the « Laboratoire d'Excellence (LabEx) » TULIP (ANR-10-LABX-41).

\section{Authors' contributions}

RHG, PA, CG and LPB have made substantial contributions to the conception and design of the work.

RHG, NMG, CG and LPB have made substantial contributions to the acquisition of data.

RHG, RDCA, AP, BF, MDR, EGJD, PA, CG and LPB have made substantial contributions to the analysis of data.

RHG, BF, EGJD, PA, CG and LPB have made substantial contributions to the interpretation of data and have written the manuscript.

All the authors, RHG, RDCA, NMG, AP, BF, MDR, EGJD, PA, CG and LPB have approved the submitted version and have agreed both to be personally accountable for the author's own contributions and to ensure that questions related to the accuracy or integrity of any part of the work, even ones in which the author was not personally involved, are appropriately investigated, resolved, and the resolution documented in the literature. 


\section{Acknowledgements}

We would like to thank Jean-François Allienne and the IHPE team (Perpignan, France) for ChIP sample preparation and sequencing. We thank Dr. Marc Bailly-Bechet, Dr. Dominique Collinet, Julie Dazenière, Dr. Georgios Koutsovoulos and Dr. Djampa Kozlowski (ISA Sophia Antipolis, France) for assistance with and discussions about data analysis and statistics. We also thank Yongpan Chen, Dr. Joffrey Mejias, Yara Nourredine, Laura Perrot and Salomé Soulé (ISA Sophia Antipolis, France) for their help in the preparation of biological materials and fruitful discussion. We also thank Dr. Michael Quentin (ISA Sophia Antipolis, France) for help with effector analysis. We thank all the members of the IPN team for insightful discussions and technical help. We also thank Corinne Rancurel and PlantBios's BIG bioinformatics platform for technical support (ISA Sophia Antipolis, France).

\section{References}

1. Singh SK, Hodda M, Ash GJ. Plant-parasitic nematodes of potential phytosanitary importance, their main hosts and reported yield losses. EPPO Bull [Internet]. 2013 Aug;43(2):334-74. Available from: http://doi.wiley.com/10.1111/epp.12050.

2. Bebber DP, Holmes T, Gurr SJ. The global spread of crop pests and pathogens. Glob Ecol Biogeogr [Internet]. 2014 Dec;23(12):1398-407. Available from: http://doi.wiley.com/10.1111/geb.12214.

3. Caillaud M-C, Dubreuil G, Quentin M, Perfus-Barbeoch L, Lecomte P, de Almeida Engler J, et al. Rootknot nematodes manipulate plant cell functions during a compatible interaction. J Plant Physiol [Internet]. 2008 Jan;165(1):104-13. Available from: https://linkinghub.elsevier.com/retrieve/pii/S0176161707001344.

4. Favery B, Dubreuil G, Chen M-S, Giron D, Abad P. Gall-Inducing Parasites: Convergent and Conserved Strategies of Plant Manipulation by Insects and Nematodes. Annu Rev Phytopathol [Internet]. 2020 Aug 25;58(1):1-22. Available from: http://www.ncbi.nlm.nih.gov/pubmed/32853101.

5. Mejias J, Truong NM, Abad P, Favery B, Quentin M. Plant Proteins and Processes Targeted by Parasitic Nematode Effectors. Front Plant Sci [Internet]. 2019 Jul 30;10:970. Available from: https://www.frontiersin.org/article/10.3389/fpls.2019.00970/full.

6. Castagnone-Sereno P. Genetic variability and adaptive evolution in parthenogenetic root-knot nematodes. Heredity (Edinb) [Internet]. 2006 Apr 11;96(4):282-9. Available from: http://www.nature.com/articles/6800794.

7. Castagnone-Sereno P, Danchin EGJ. Parasitic success without sex - the nematode experience. J Evol Biol [Internet]. 2014 Jul;27(7):1323-33. Available from: http://doi.wiley.com/10.1111/jeb.12337.

8. Koutsovoulos GD, Marques E, Arguel M, Duret L, Machado ACZ, Carneiro RMDG, et al. Population genomics supports clonal reproduction and multiple independent gains and losses of parasitic abilities in the most devastating nematode pest. Evol Appl [Internet]. 2020 Feb 6;13(2):442-57. Available from: https://onlinelibrary.wiley.com/doi/abs/10.1111/eva.12881. 
9. Asamizu E, Shirasawa K, Hirakawa H, Iwahori H. Root-knot nematode genetic diversity associated with host compatibility to sweetpotato cultivars. Mol Plant Pathol [Internet]. 2020 Aug 17;21(8):1088-98. Available from: https://onlinelibrary.wiley.com/doi/abs/10.1111/mpp.12961.

10. Kozlowski DKL, Hassanaly-Goulamhoussen R, Da Rocha M, Koutsovoulos GD, Bailly-Bechet M, Danchin EGJ. Movements of transposable elements contribute to the genomic plasticity and species diversification in an asexually reproducing nematode pest. Evol Appl [Internet]. 2021 May 5;eva.13246. Available from: https://onlinelibrary.wiley.com/doi/10.1111/eva.13246.

11. Castagnone-Sereno P, Mulet K, Danchin EGJ, Koutsovoulos GD, Karaulic M, Da Rocha M, et al. Gene copy number variations as signatures of adaptive evolution in the parthenogenetic, plant-parasitic nematode Meloidogyne incognita. Mol Ecol [Internet]. 2019 May 29;28(10):2559-72. Available from: https://onlinelibrary.wiley.com/doi/abs/10.1111/mec.15095.

12. Choi JY, Lee YCG. Double-edged sword: The evolutionary consequences of the epigenetic silencing of transposable elements. Betancourt A, editor. PLOS Genet [Internet]. 2020 Jul 16 [cited 2021 Apr 22];16(7):e1008872. Available from: https://doi.org/10.1371/journal.pgen.1008872.

13. Gornik SG, Ford KL, Mulhern TD, Bacic A, McFadden GI, Waller RF. Loss of Nucleosomal DNA Condensation Coincides with Appearance of a Novel Nuclear Protein in Dinoflagellates. Curr Biol [Internet]. 2012 Dec;22(24):2303-12. Available from: https://linkinghub.elsevier.com/retrieve/pii/S0960982212012572.

14. Talbert PB, Henikoff S. Histone variants - ancient wrap artists of the epigenome. Nat Rev Mol Cell Biol [Internet]. 2010 Apr 3;11(4):264-75. Available from: http://www.nature.com/articles/nrm2861.

15. Soyer JL, El Ghalid M, Glaser N, Ollivier B, Linglin J, Grandaubert J, et al Epigenetic Control of Effector Gene Expression in the Plant Pathogenic Fungus Leptosphaeria maculans. Talbot NJ, editor. PLoS Genet [Internet]. 2014 Mar 6;10(3):e1004227. Available from:

https://dx.plos.org/10.1371/journal.pgen.1004227.

16. Strahl BD, Allis CD. The language of covalent histone modifications. Nature [Internet]. 2000 Jan 6;403(6765):41-5. Available from: http://www.ncbi.nlm.nih.gov/pubmed/10638745.

17. O'Kane CJ, Hyland EM. Yeast epigenetics: the inheritance of histone modification states. Biosci Rep [Internet]. 2019 May 31;39(5). Available from: https://portlandpress.com/bioscirep/article/doi/10.1042/BSR20182006/219163/Yeast-epigeneticsthe-inheritance-of-histone.

18. Meyer CA, Liu XS. Identifying and mitigating bias in next-generation sequencing methods for chromatin biology. Nat Rev Genet [Internet]. 2014 Nov 16;15(11):709-21. Available from: http://www.nature.com/articles/nrg3788.

19. Weinhouse C, Truong L, Meyer JN, Allard P. Caenorhabditis elegans as an emerging model system in environmental epigenetics. Environ Mol Mutagen [Internet]. 2018 Aug;59(7):560-75. Available from: http://doi.wiley.com/10.1002/em.22203.

20. Perfus-Barbeoch L, Castagnone-Sereno P, Reichelt M, Fneich S, Roquis D, Pratx L, et al. Elucidating 
nematode Meloidogyne incognita. Front Physiol [Internet]. 2014 Jun 6;5. Available from: http://journal.frontiersin.org/article/10.3389/fphys.2014.00211/abstract.

21. Pratx L, Rancurel $C$, Rocha M, Da, Danchin EGJ, Castagnone-Sereno P, Abad P, et al. Genome-wide expert annotation of the epigenetic machinery of the plant-parasitic nematodes Meloidogyne spp., with a focus on the asexual species. BMC Genomics. 2017.

22. Wenzel D, Palladino F, Jedrusik-Bode M. Epigenetics in C. elegans: Facts and challenges. genesis [Internet]. 2011 Aug;49(8):647-61. Available from: http://doi.wiley.com/10.1002/dvg.20762.

23. Greer EL, Blanco MA, Gu L, Sendinc E, Liu J, Aristizábal-Corrales D, et al. DNA Methylation on N6Adenine in C. elegans. Cell [Internet]. 2015 May 7;161(4):868-78. Available from: http://www.ncbi.nlm.nih.gov/pubmed/25936839.

24. Mitreva M, Jasmer DP, Zarlenga DS, Wang Z, Abubucker S, Martin J, et al. The draft genome of the parasitic nematode Trichinella spiralis. Nat Genet [Internet]. 2011 Mar 20;43(3):228-35. Available from: http://www.nature.com/articles/ng.769.

25. Hewezi T. Epigenetic Mechanisms in Nematode-Plant Interactions. Annu Rev Phytopathol [Internet]. 2020 Aug 25;58(1):119-38. Available from: https://www.annualreviews.org/doi/10.1146/annurevphyto-010820-012805.

26. Cosseau C, Azzi A, Smith K, Freitag M, Mitta G, Grunau C. Native chromatin immunoprecipitation (NChIP) and ChIP-Seq of Schistosoma mansoni: Critical experimental parameters. Mol Biochem Parasitol [Internet]. 2009 Jul;166(1):70-6. Available from: https://linkinghub.elsevier.com/retrieve/pii/S0166685109000772.

27. Blanc-Mathieu R, Perfus-Barbeoch L, Aury J-M, Da Rocha M, Gouzy J, Sallet E, et al Hybridization and polyploidy enable genomic plasticity without sex in the most devastating plant-parasitic nematodes. Gojobori T, editor. PLOS Genet [Internet]. 2017 Jun 8;13(6):e1006777. Available from: https://dx.plos.org/10.1371/journal.pgen.1006777.

28. Taudt A, Nguyen MA, Heinig M, Johannes F, Colome-Tatche M. chromstaR: Tracking combinatorial chromatin state dynamics in space and time. bioRxiv. 2016; Available from: https://doi.org/10.1101/038612.

29. Stillman B. Histone Modifications: Insights into Their Influence on Gene Expression. Cell [Internet]. 2018 Sep;175(1):6-9. Available from: https://linkinghub.elsevier.com/retrieve/pii/S0092867418310481.

30. Bian Q, Anderson EC, Yang Q, Meyer BJ. Histone. H3K9 methylation promotes formation of genome compartments in Caenorhabditis elegans via chromosome compaction and perinuclear anchoring. Proc Natl Acad Sci [Internet]. 2020 May 26;117(21):11459-70. Available from: http://www.pnas.org/lookup/doi/10.1073/pnas.2002068117.

31. Da Rocha M, Bournaud C, Dazenière J, Thorpe P, Pellegrin C, Bailly-Bechet $M$, Péré A, Grynberg $P$, Perfus-Barbeoch L, Eves-vanden Akker S. Danchin E.G.J. Genome expression dynamics reveals parasitism regulatory landscape of the root-knot nematode Meloidogyne incognita and a promoter 
32. Nguyen C-N, Perfus-Barbeoch L, Quentin M, Zhao J, Magliano M, Marteu N, et al. A root-knot nematode small glycine and cysteine-rich secreted effector, MiSGCR1, is involved in plant parasitism. New Phytol [Internet]. 2018 Jan;217(2):687-99. Available from: http://doi.wiley.com/10.1111/nph.14837.

33. Ahringer J, Gasser SM. Repressive Chromatin in Caenorhabditis elegans: Establishment, Composition, and Function. Genetics [Internet]. 2018 Feb;208(2):491-511. Available from: https://academic.oup.com/genetics/article/208/2/491-511/6088083.

34. Barski A, Cuddapah S, Cui K, Roh T-Y, Schones DE, Wang Z, et al. High-Resolution Profiling of Histone Methylations in the Human Genome. Cell [Internet]. 2007 May;129(4):823-37. Available from: https://linkinghub.elsevier.com/retrieve/pii/S0092867407006009.

35. Garcia BA, Hake SB, Diaz RL, Kauer M, Morris SA, Recht J, et al. Organismal Differences in Posttranslational Modifications in Histones H3 and H4. J Biol Chem [Internet]. 2007 Mar;282(10):764155. Available from: https://linkinghub.elsevier.com/retrieve/pii/S0021925820636079.

36. Tessarz $P$, Kouzarides T. Histone core modifications regulating nucleosome structure and dynamics. Nat Rev Mol Cell Biol [Internet]. 2014 Nov 15;15(11):703-8. Available from: http://www.nature.com/articles/nrm3890.

37. Lin B, Lee H, Yoon J-G, Madan A, Wayner E, Tonning S, et al. Global analysis of H3K4me3 and H3K27me3 profiles in glioblastoma stem cells and identification of SLC17A7 as a bivalent tumor suppressor gene. Oncotarget [Internet]. 2015 Mar 10;6(7):5369-81. Available from: http://www.ncbi.nlm.nih.gov/pubmed/25749033.

38. Zang C, Schones DE, Zeng C, Cui K, Zhao K, Peng W. A clustering approach for identification of enriched domains from histone modification ChIP-Seq data. Bioinformatics [Internet]. 2009 Aug 1;25(15):1952-8. Available from: https://academic.oup.com/bioinformatics/articlelookup/doi/10.1093/bioinformatics/btp340.

39. Oda H, Okamoto I, Murphy N, Chu J, Price SM, Shen MM, et al. Monomethylation of Histone H4Lysine 20 Is Involved in Chromosome Structure and Stability and Is Essential for Mouse Development. Mol Cell Biol [Internet]. 2009 Apr 15;29(8):2278-95. Available from: https://mcb.asm.org/content/29/8/2278.

40. SHIKATA D, YAMAMOTO T, HONDA S, IKEDA S, MINAMI N. H4K20 monomethylation inhibition causes loss of genomic integrity in mouse preimplantation embryos. J Reprod Dev [Internet]. 2020;66(5):411-9. Available from: https://www.jstage.jst.go.jp/article/jrd/66/5/66_2020036/_article.

41. Lachner M, O'Carroll D, Rea S, Mechtler K, Jenuwein T. Methylation of histone H3 lysine 9 creates a binding site for HP1 proteins. Nature [Internet]. 2001 Mar;410(6824):116-20. Available from: http://www.nature.com/articles/35065132.

42. Ninova M, Fejes Tóth $\mathrm{K}$, Aravin AA. The control of gene expression and cell identity by H3K9 trimethylation. Development [Internet]. 2019 Oct 1;146(19):dev181180. Available from: httn.//dev hinlnaicte nra/lnnkun/dni/1n 124)/dev 181180.

Loading [MathJax]/jax/output/CommonHTML/fonts/TeX/fontdata.js

Page 30/40 
43. He J, Fu X, Zhang M, He F, Li W, Abdul MM, et al. Transposable elements are regulated by contextspecific patterns of chromatin marks in mouse embryonic stem cells. Nat Commun [Internet]. 2019 Dec 3;10(1):34. Available from: http://www.nature.com/articles/s41467-018-08006-y.

44. Dong $X$, Weng $Z$. The correlation between histone modifications and gene expression. Epigenomics [Internet]. 2013 Apr;5(2):113-6. Available from: https://www.futuremedicine.com/doi/10.2217/epi.13.13.

45. Tie F, Banerjee R, Stratton CA, Prasad-Sinha J, Stepanik V, Zlobin A, et al. CBP-mediated acetylation of histone H3 lysine 27 antagonizes Drosophila Polycomb silencing. Development [Internet]. 2009 Sep 15;136(18):3131-41. Available from: http://dev.biologists.org/cgi/doi/10.1242/dev.037127.

46. Boyer LA, Plath K, Zeitlinger J, Brambrink T, Medeiros LA, Lee TI, et al. Polycomb complexes repress developmental regulators in murine embryonic stem cells. Nature [Internet]. 2006 May 19;441(7091):349-53. Available from: http://www.nature.com/articles/nature04733.

47. Bracken AP. Genome-wide mapping of Polycomb target genes unravels their roles in cell fate transitions. Genes Dev [Internet]. 2006 May 1;20(9):1123-36. Available from: http://www.genesdev.org/cgi/doi/10.1101/gad.381706.

48. Battle SL, Doni Jayavelu N, Azad RN, Hesson J, Ahmed FN, Overbey EG, et al. Enhancer Chromatin and 3D Genome Architecture Changes from Naive to Primed Human Embryonic Stem Cell States. Stem Cell Reports [Internet]. 2019 May;12(5):1129-44. Available from: https://linkinghub.elsevier.com/retrieve/pii/S2213671119301262.

49. Ngo V, Chen Z, Zhang K, Whitaker JW, Wang M, Wang W. Epigenomic analysis reveals DNA motifs regulating histone modifications in human and mouse. Proc Natl Acad Sci [Internet]. 2019 Feb 26;116(9):3668-77. Available from: http://www.pnas.org/lookup/doi/10.1073/pnas.1813565116.

50. Zhang T, Zhang Z, Dong Q, Xiong J, Zhu B. Histone. H3K27 acetylation is dispensable for enhancer activity in mouse embryonic stem cells. Genome Biol [Internet]. 2020 Dec 21;21(1):45. Available from: https://genomebiology.biomedcentral.com/articles/10.1186/s13059-020-01957-w.

51. Li F, Wan M, Zhang B, Peng Y, Zhou Y, Pi C, et al. Bivalent Histone Modifications and Development. Curr Stem Cell Res Ther [Internet]. 2018 Jan 19;13(2). Available from: http://www.eurekaselect.com/149449/article.

52. Alla RK, Cairns BR. RNA Polymerase III Transcriptomes in Human Embryonic Stem Cells and Induced Pluripotent Stem Cells, and Relationships with Pluripotency Transcription Factors. Emanueli C, editor. PLoS One [Internet]. 2014 Jan 20;9(1):e85648. Available from: https://dx.plos.org/10.1371/journal.pone.0085648.

53. Connolly LR, Smith KM, Freitag M. The Fusarium graminearum Histone H3 K27 Methyltransferase KMT6 Regulates Development and Expression of Secondary Metabolite Gene Clusters. Madhani HD, editor. PLoS Genet [Internet]. 2013 Oct 31;9(10):e1003916. Available from: https://dx.plos.org/10.1371/journal.pgen.1003916.

54. Soyer JL, Rouxel T, Fudal I. Chromatin-based control of effector gene expression in plant-associated 6. Available from: 
https://linkinghub.elsevier.com/retrieve/pii/S136952661500076X.

55. Meile L, Peter J, Puccetti G, Alassimone J, McDonald BA, Sánchez-Vallet A. Chromatin Dynamics Contribute to the Spatiotemporal Expression Pattern of Virulence Genes in a Fungal Plant Pathogen. Di Pietro A, editor. MBio [Internet]. 2020 Oct 6;11(5). Available from: https://mbio.asm.org/content/11/5/e02343-20.

56. Huang G, Dong R, Allen R, Davis EL, Baum TJ, Hussey RS. Developmental expression and molecular analysis of two Meloidogyne incognita pectate lyase genes. Int J Parasitol [Internet]. 2005 May;35(6):685-92. Available from: https://linkinghub.elsevier.com/retrieve/pii/S0020751905000408.

57. Sacco MA, Koropacka K, Grenier E, Jaubert MJ, Blanchard A, Goverse A, et al. The Cyst Nematode SPRYSEC Protein RBP-1 Elicits Gpa2- and RanGAP2-Dependent Plant Cell Death. Opperman C, editor. PLoS Pathog [Internet]. 2009 Aug 28;5(8):e1000564. Available from: http://www.ncbi.nlm.nih.gov/pubmed/19714238.

58. Caillaud M-C, Favery B. In Vivo Imaging of Microtubule Organization in Dividing Giant Cell. In: Methods in Molecular Biology [Internet]. 2016. p. 137-44. Available from: http://link.springer.com/10.1007/978-1-4939-3142-2_11.

59. Park PJ. ChIP-seq: advantages and challenges of a maturing technology. Nat Rev Genet [Internet]. 2009 Oct 8;10(10):669-80. Available from: http://www.nature.com/articles/nrg2641.

60. Andrews S. FastQC - A quality control tool for high throughput sequence data. http://www.bioinformatics.babraham.ac.uk/projects/fastqc/. Babraham Bioinformatics. 2010.

61. Langmead B, Salzberg SL. Fast gapped-read alignment with Bowtie 2. Nat Methods [Internet]. 2012 Mar 4;9(4):357-9. Available from: http://www.ncbi.nlm.nih.gov/pubmed/22388286.

62. Feng X, Grossman R, Stein L. PeakRanger:. A cloud-enabled peak caller for ChIP-seq data. BMC Bioinformatics [Internet]. 2011 Dec 9;12(1):139. Available from: https://bmcbioinformatics.biomedcentral.com/articles/10.1186/1471-2105-12-139.

63. Robinson JT, Thorvaldsdóttir $\mathrm{H}$, Wenger AM, Zehir A, Mesirov JP. Variant Review with the Integrative Genomics Viewer. Cancer Res [Internet]. 2017 Nov 1;77(21):e31-4. Available from: http://cancerres.aacrjournals.org/lookup/doi/10.1158/0008-5472.CAN-17-0337.

64. Danchin EGJ, Da Rocha MM. incognita protein-coding genes expression patterns. Portail Data INRAE [Internet]. Available from: https://doi.org/10.15454/YM2DHE. 2020.

65. Danchin EGJ, Arguel M-J, Campan-Fournier A, Perfus-Barbeoch L, Magliano M, Rosso M-N, et al Identification of Novel Target Genes for Safer and More Specific Control of Root-Knot Nematodes from a Pan-Genome Mining. Ghedin E, editor. PLoS Pathog [Internet]. 2013 Oct 31;9(10):e1003745. Available from: https://dx.plos.org/10.1371/journal.ppat.1003745.

66. Love MI, Huber W, Anders S. Moderated estimation of fold change and dispersion for RNA-seq data with DESeq2. Genome Biol [Internet]. 2014 Dec 5;15(12):550. Available from: http://genomebiology.biomedcentral.com/articles/10.1186/s13059-014-0550-8. 
67. Thomas PD. PANTHER: A Library of Protein Families and Subfamilies Indexed by Function. Genome Res [Internet]. 2003 Sep 1;13(9):2129-41. Available from:

http://www.genome.org/cgi/doi/10.1101/gr.772403.

\section{Figures}

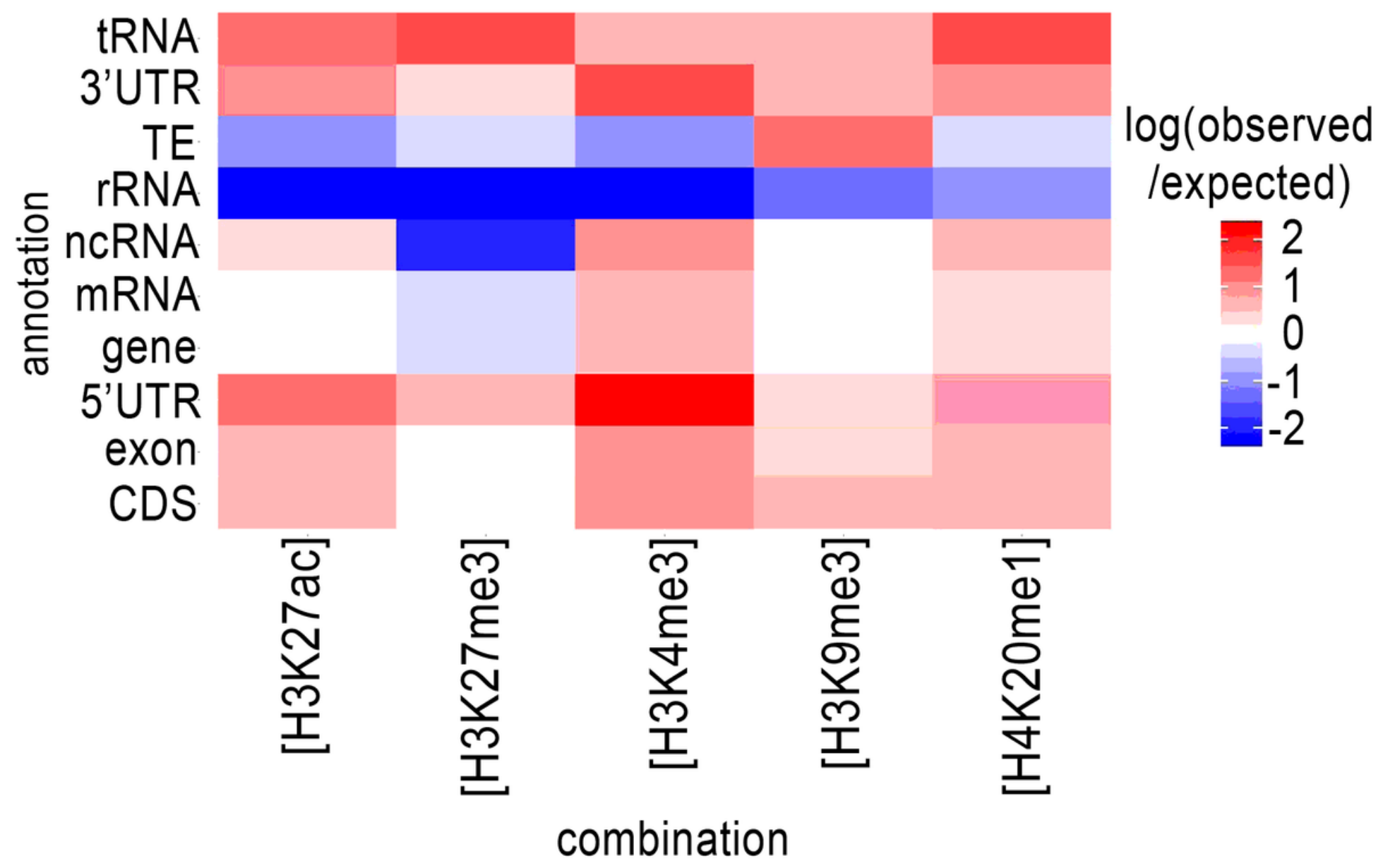

Figure 1

Genome wide distribution of histone modifications in relation to annotations for the M. incognita genome. The distribution of histone modifications was analyzed with ChromstaR, which calculated the spatial enrichment in histone modifications for different available genomic annotations. Enrichment is represented as the log(observed/expected) value and ranges from 2 (highly enriched, red) to -2 (depletion, blue). This enrichment heatmap is a $5 \times 10$ matrix representing 5 histone modifications (H3K4me3, H3K9me3, H3K27ac, H3K27me3 and H4K20me1) and 10 genomic annotated elements (CDS, exon, five prime UTR, gene, mRNA, ncRNA, rRNA, TE, three prime UTR and tRNA). Three biological replicates of M. incognita eggs have been treated jointly to identify common histone modification enrichment. 


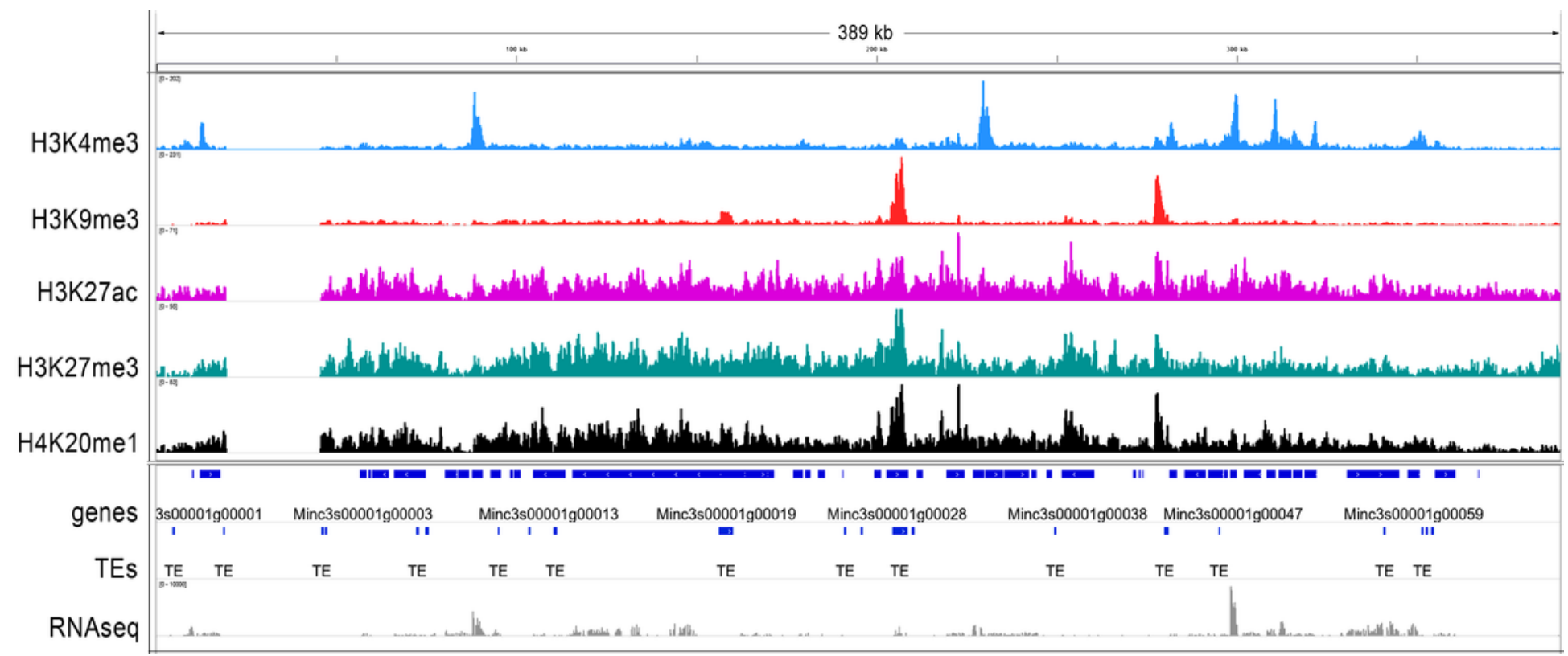

Figure 2

H3K4me3, H3K9me3, H3K27ac, H27me3 and H4K20me1 histone modifications on the M. incognita genome. The general tracks of histone modifications are illustrated on the longest scaffold (Minc3s00001) of the M.incognita genome. Sequence reads for H3K4me3 (blue), H3K9me3 (red), H3K27ac (pink), H3K27me3 (green) and H4K20me1 (black) samples were visualized in IGV software. Values shown on the $y$ axis represent the relative enrichment of ChIP-Seq signals obtained with PeakRanger (peaks correspond to read counts after background/input subtraction). The tracks were overlaid with the M. incognita's annotations (dark blue) of Genes and Transposable Elements (TE), as well as RNA-seq reads (grey). Each track contains information from one biological replicate of eggs. 


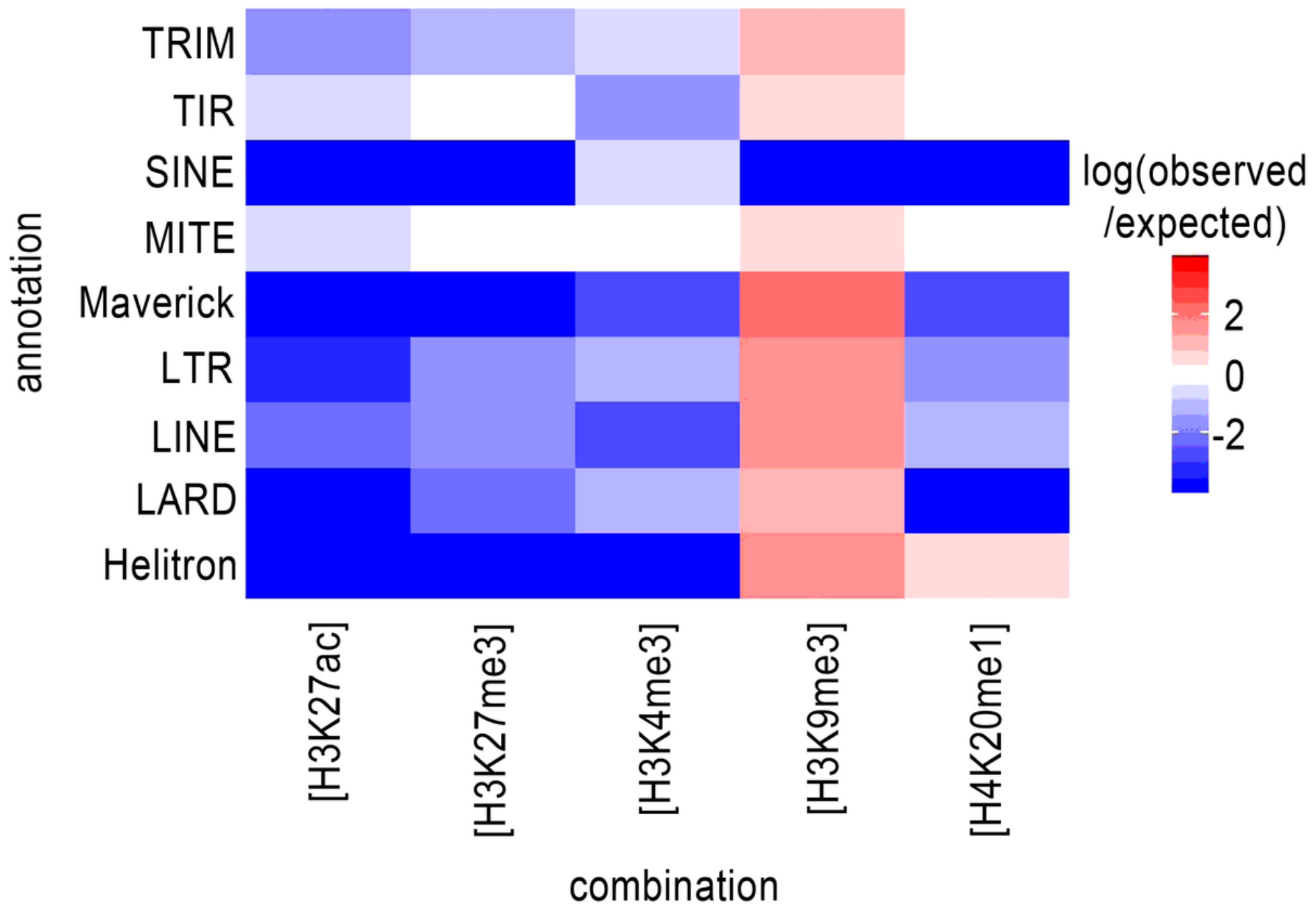

Figure 3

Distribution of histone modifications in relation to transposable element (TE) orders. The distribution of histone modifications was analyzed with ChromstaR, which calculated the spatial enrichment in histone modifications for annotated subfamilies of TE in M. incognita. Enrichment is represented as the $\log$ (observed/expected) value and ranges from 2 (highly enriched, red) to -2 (depletion, blue). This enrichment heatmap is a $5 \times 11$ matrix representing 5 histone modifications (H3K4me3, H3K9me3, H3K27ac, H3K27me3 and H4K20me1) and 11 TE orders (4 DNA-transposons (Helitron, Maverick, TIR, MITE), and 5 RNA transposons (LINE, LTR, SINE, LARD and TRIM)). Three biological replicates of M. incognita eggs have been treated jointly to identify common histone modification enrichment. 


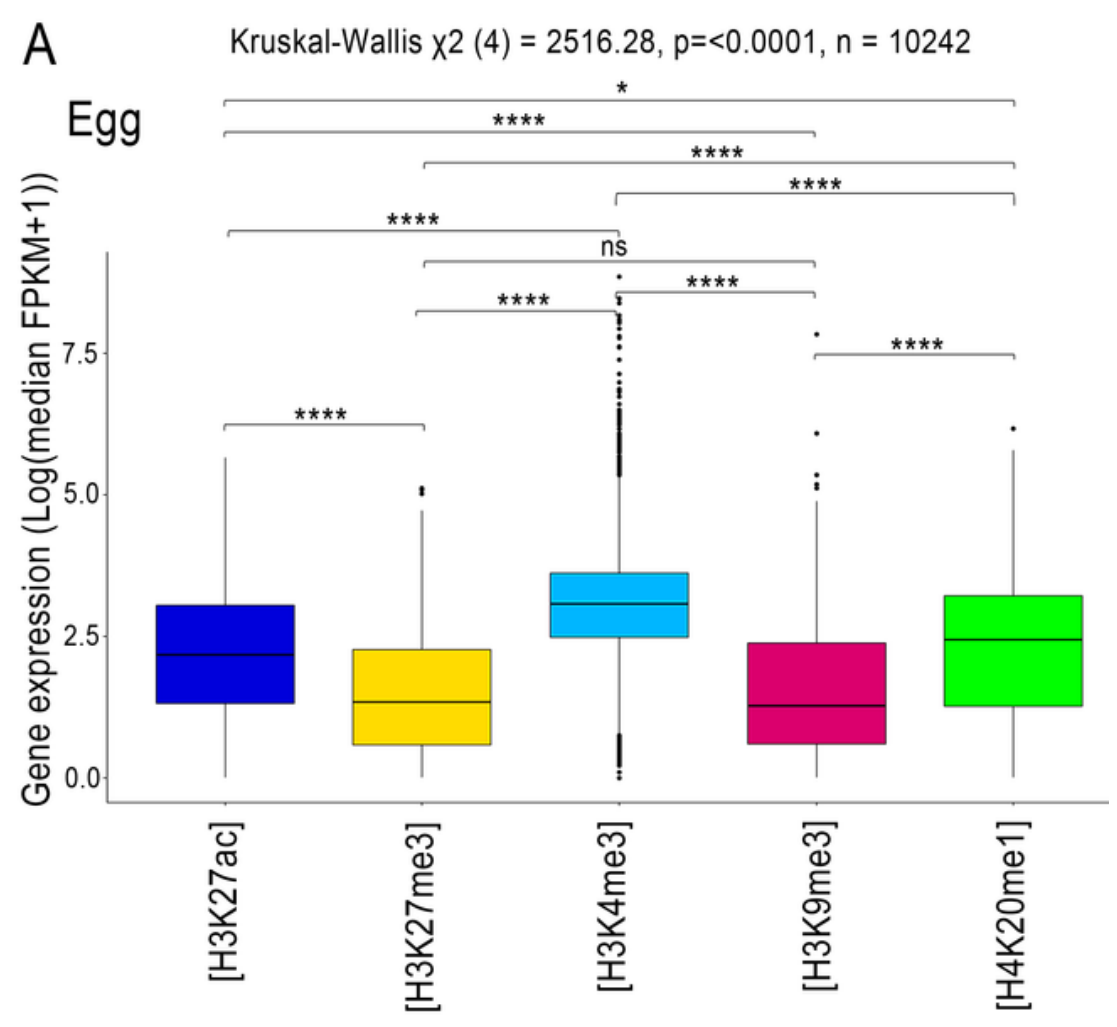

B Kruskal-Wallis $\times 2(4)=3548.76, p=<0.0001, n=18577$

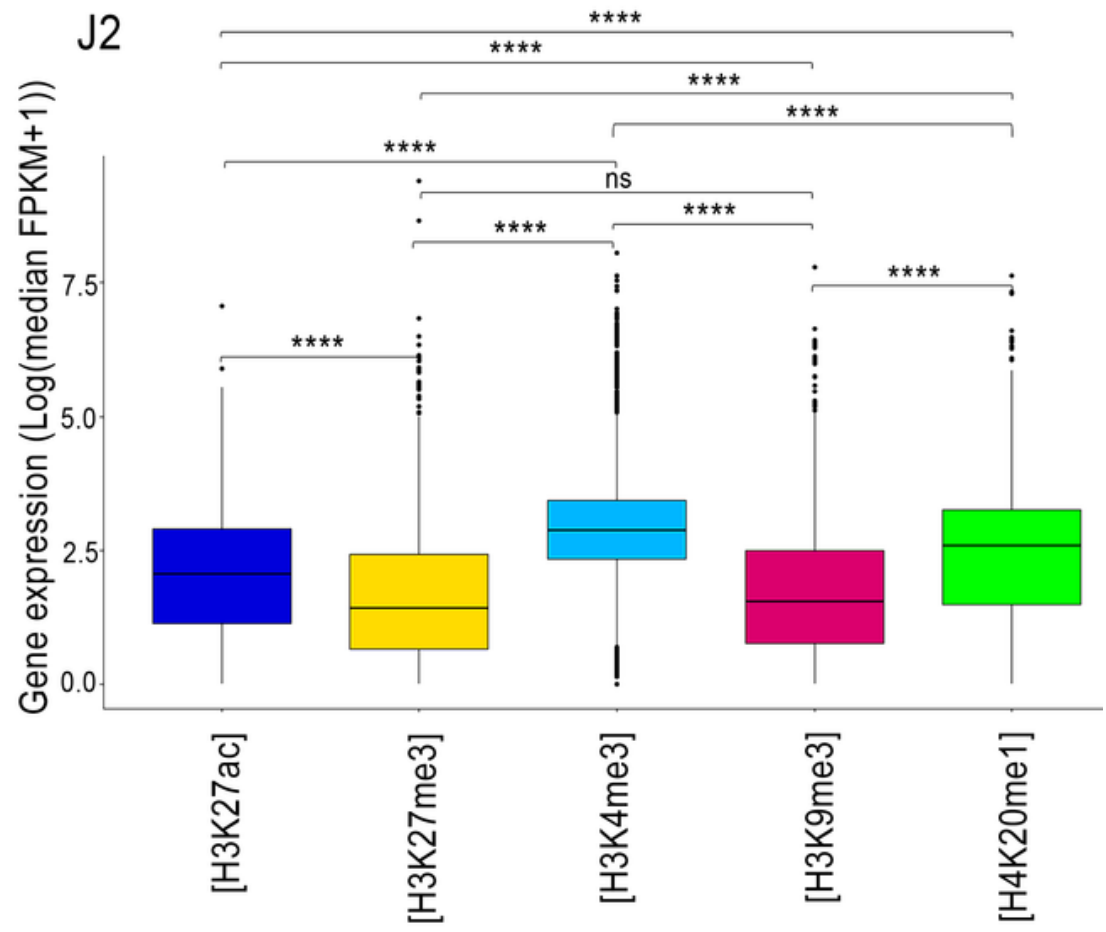

Figure 4

RNA-seq regulation of the protein-coding genes associated with histone modifications. Analysis of transcript levels of the genes associated with H3K27ac (blue), H3K27me3 (yellow), H3K4me3 (sky blue), H3K9me3 (dark pink) and H4K20me1 (green) in (A) Eggs and (B) J2s. Genes were considered to be associated with a histone modification if at least $1 \mathrm{bp}$ of the annotation overlapped with an identified Loading [MathJax]/jax/output/CommonHTML/fonts/TeX/fontdata.js ognita eggs and J2s have been treated jointly to 
identify common histone modification enrichment using ChromstaR. Normalized expression (Log(median FPKM+1) of genes, calculated triplicates is shown. A Kruskal-Wallis test was performed, followed by a pairwise Dunn test, to assess the significance of differences in gene expression level between the 5 histone modifications. ns $p>0.05, * p \leq 0.05, * * p \leq 0.01, * * * p \leq 0.001, * * * * p \leq 0.0001$.
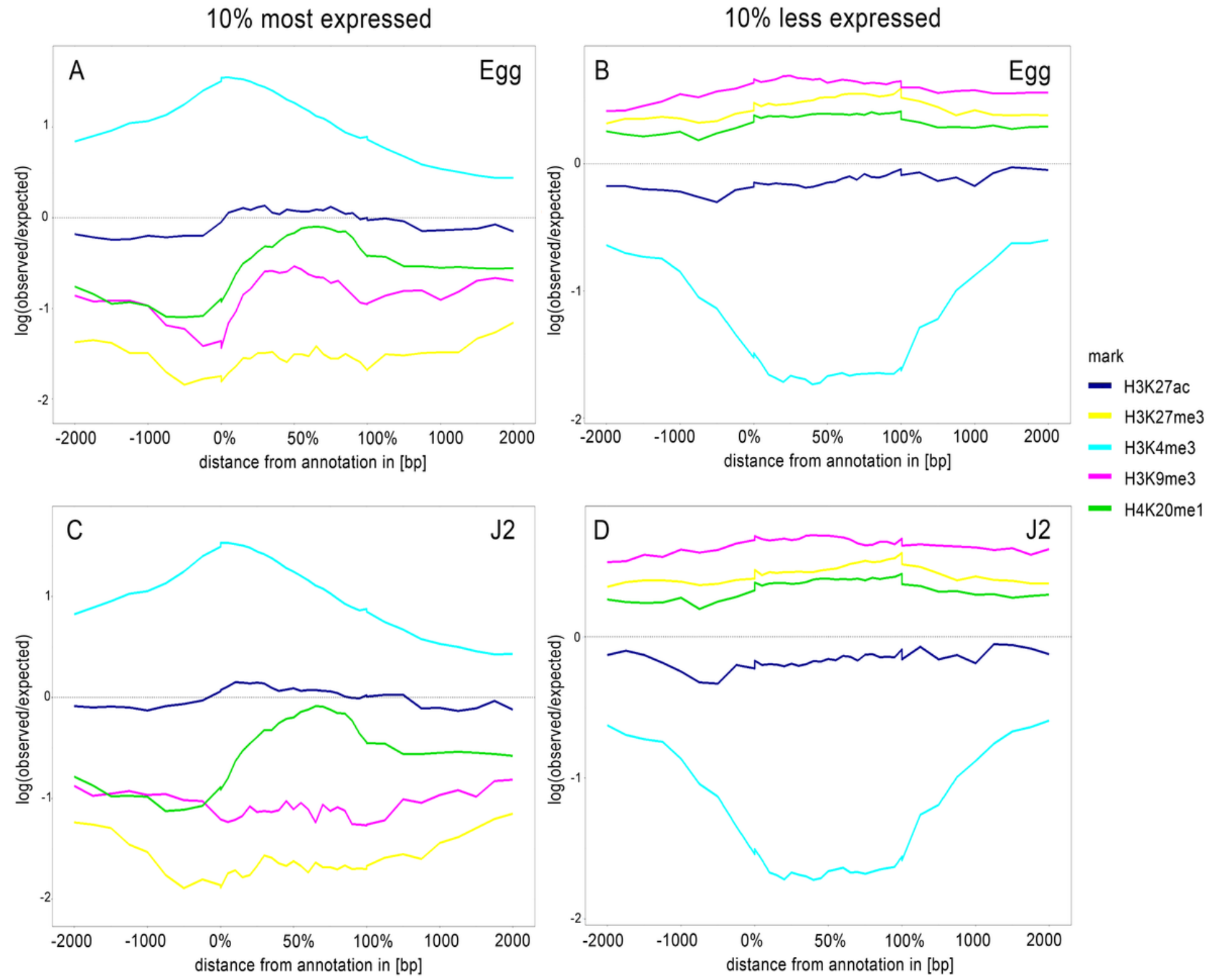

Figure 5

Average H3K4me3 enrichment profiles correlate with TSS regions of 10\% most expressed genes. Average enrichment profiles of 5 histone modifications along a $4 \mathrm{~kb}$ region framing expressed protein-coding genes after ChIP-Seq of (A and $B$ ) eggs and (B and D) J2s. Average enrichment profiles were generated by ChromstaR, (log(observed/expected) value ranging from 1 (highly enriched) to -2 (depletion)), for 5 histone modifications: H3K27ac (blue), H3K27me3 (yellow), H3K4me3 (sky blue), H3K9me3 (dark pink) and H4K20me1 (green). Three biological replicates of M. incognita eggs and J2s have been treated Loading [MathJax]/jax/output/CommonHTML/fonts/TeX/fontdata.js 
top and (B and $D$ ) bottom $10 \%$ of associated protein-coding genes ranked on the basis of RNA-seq normalized expression data ( $\log ($ median FPKM+1). $x$-axis: \% in gene bodies and distance in bp upstream of TSS or downstream of TES. y-axis: Density of mapped reads (log(observed/expected).

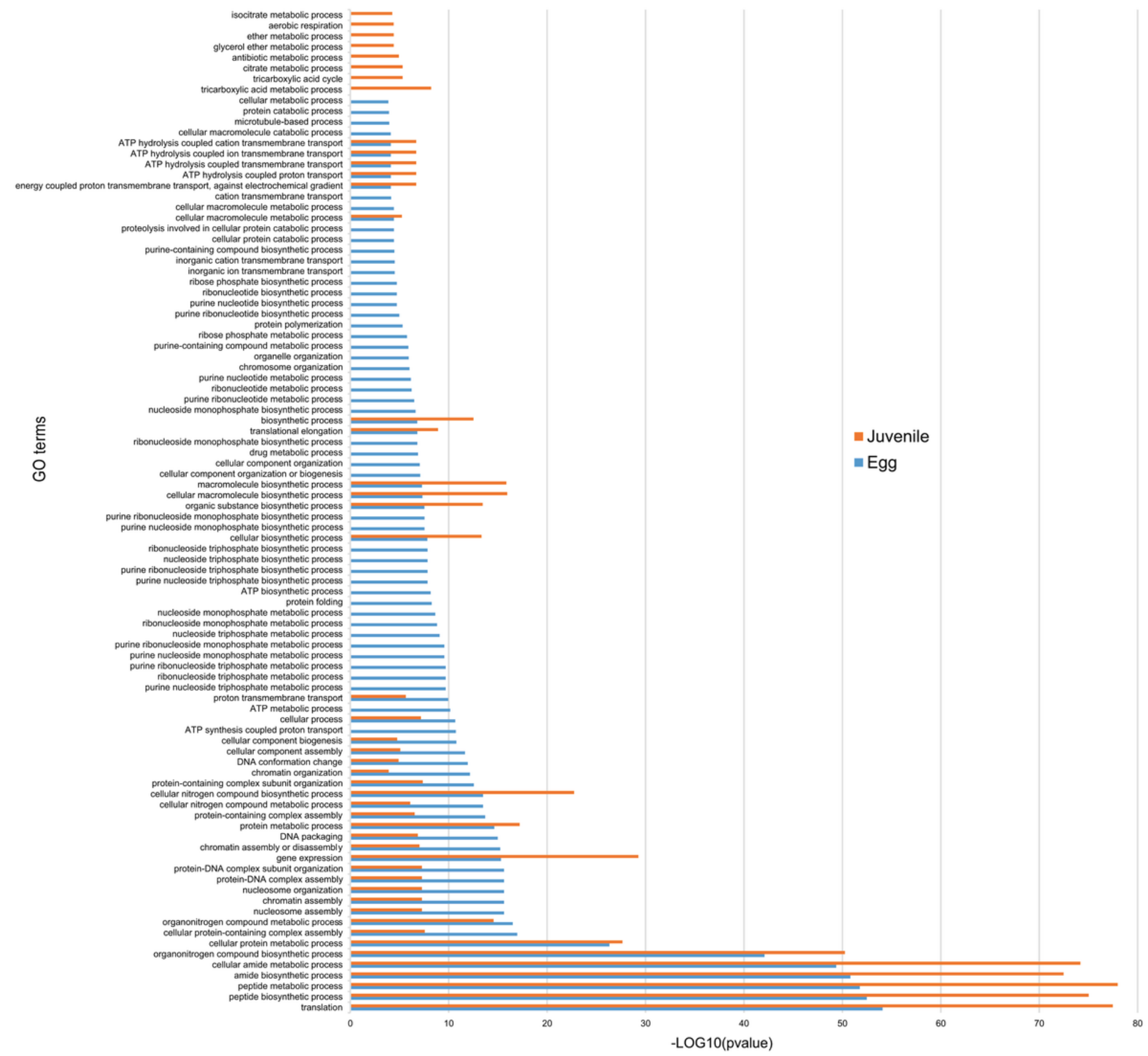

\section{Figure 6}

Functional annotation of protein-coding genes associated with H3K4me3. Histogram showing the 'Biological processes'/Gene ontology (GO) term enrichment of protein-coding genes associated with $\mathrm{H} 3 \mathrm{~K} 4 \mathrm{me}$. Protein-coding genes were considered to be associated with H3K4me3 if at least $1 \mathrm{bp}$ of the protein-coding gene annotation overlapped with this histone modification. Three biological replicates of $M$. incognita eggs and J2s have been treated jointly to identify common histone modification enrichment. Loading [MathJax]/jax/output/CommonHTML/fonts/TeX/fontdata.js d J2s (orange, 10,564 genes), were identified 
with GoFuncR with a FWER $<0.05$ cutoff. X-axis is the -log10(pvalue) calculated to represent GO term enrichment on the bar chart.

mitotic nuclear division

nuclear chromosome segregation chromosome segregation sister chromatid segregation nuclear division

mitotic sister chromatid segregation regulation of mitotic cell cycle phase transition regulation of cell cycle phase transition mitotic cell cycle phase transition cell cycle phase transition regulation of cell cycle process regulation of mitotic cell cycle cellular process mitotic cell cycle mitotic cell cycle process cell cycle

DNA-dependent DNA replication cell cycle process

DNA replication initiation protein polymerization microtubule-based process organelle organization chromosome organization chromatin organization

cellular component organization or biogenesis cellular component organization chromatin assembly or disassembly cellular component biogenesis

protein-DNA complex subunit organization protein-DNA complex assembly nucleosome organization chromatin assembly nucleosome assembly DNA conformation change DNA packaging

cellular component assembly protein-containing complex subunit organization protein-containing complex assembly cellular protein-containing complex assembly cellular response to stimulus response to stimulus biological regulation regulation of cellular process regulation of biological process cell communication signaling signal transduction G protein-coupled receptor signaling pathway

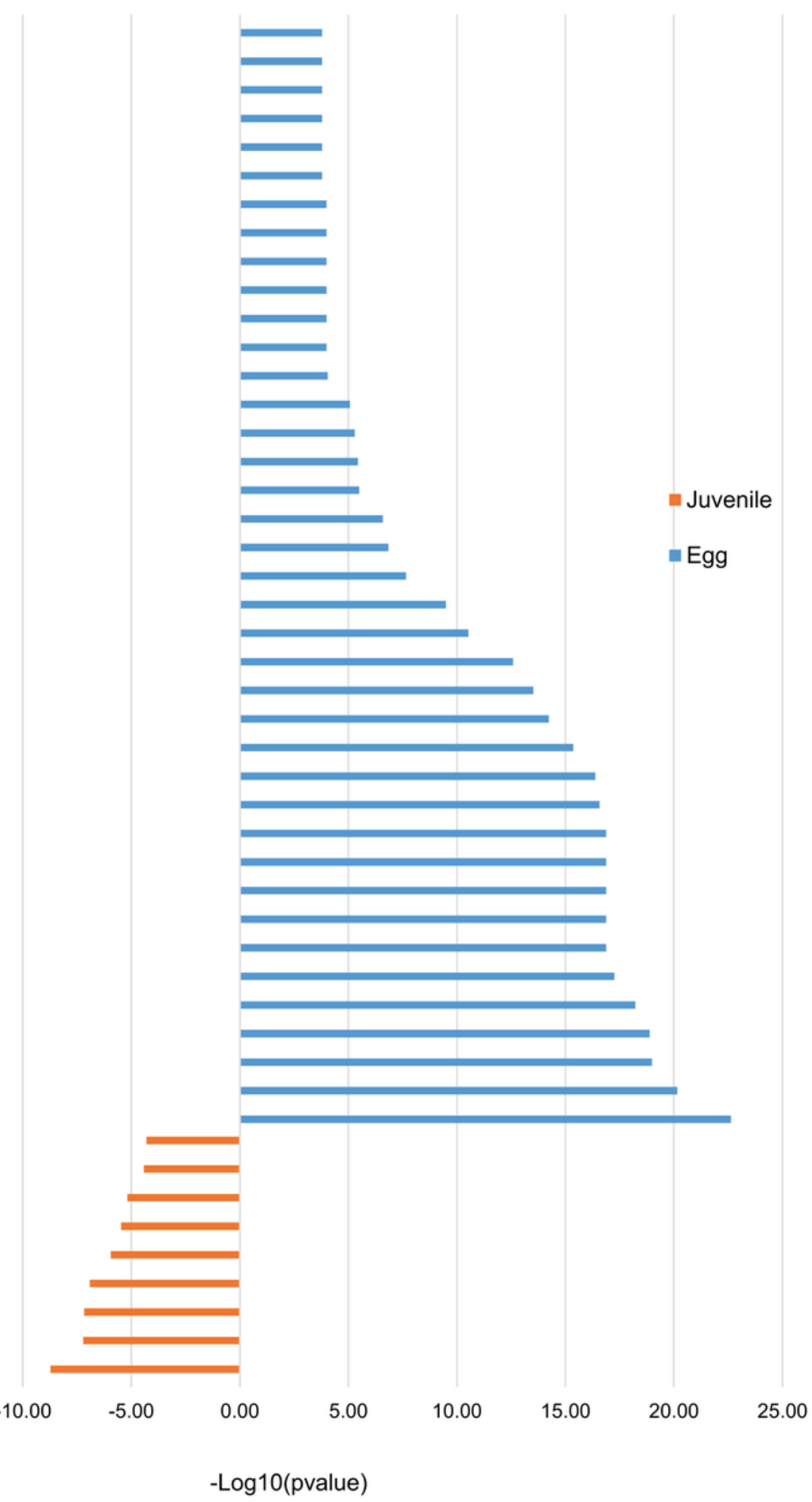

\section{Figure 7}

Stage-specific enrichment in Gene Ontology (GO) terms for protein-coding genes associated with H3K4me3. Histogram showing the "Biological processes"/GO term enrichment of protein-coding genes 
Differential gene expression was calculated using DESeq2 on triplicates, with a $p$ value $<0.05$ as a threshold for overexpression. Protein-coding genes were considered to be associated with H3K4me3 if at least $1 \mathrm{bp}$ of the protein-coding gene annotation overlapped with this histone modification. Three biological replicates of $\mathrm{M}$. incognita eggs and $\mathrm{J} 2 \mathrm{~s}$ have been treated jointly to identify common histone modification enrichment. Overrepresented GO terms, in eggs (blue ; 89 genes) and J2s (orange, 117 genes), were identified with GoFuncR. with a FWER $<0.05$ cutoff. X-axis is the -log 10 (pvalue) calculated to represent $\mathrm{GO}$ term enrichment on the bar chart.

\section{Supplementary Files}

This is a list of supplementary files associated with this preprint. Click to download.

- Supplementarymaterial.docx 